\title{
BAL ARILARINDA SOSYAL VE BİREYSEL BAĞIŞIKLIK
}

\author{
Social Immunity and Individual Immunity in Honey Bees
}

\begin{abstract}
A.Ebru BORUM
Balıkesir Üniversitesi, Veteriner Fakültesi, Mikrobiyoloji Anabilim Dalı, Balıkesir, TÜRKIYE, ORCID No: 0000-0002-69168982, Yazışma Yazarı/Corresponding author: E-posta: ebruborum@balikesir.edu.tr

Geliş Tarihi / Received: 04.09.2020

Kabul Tarihi / Accepted: 13.10.2020

DOI:10.31467/uluaricilik.790629

\section{ÖZ}

Bal arıları, doğal ekosistem ve tarımsal alanda tozlaşmada oldukça önemli rol oynarlar. Patojenler (Parazit, mantar, virüs ve bakteriler), ekosistem değişikliği ya da kayıpları, zirai kimyasal kullanımı gibi birçok biyotik ve abiyotik stres faktörü tek başına ya da birlikte arı kolonisinin, sağlık ve yaşamını olumsuz olarak etkilemektedir. Tüm bu faktörler arıların bağışıklık sistemini etkileyerek savunma mekanizmalarını değiştirir. Bal arıları kendilerini infeksiyöz ve paraziter etkenlere karşı korumak için fiziksel bariyerler, genelleşmiş hücresel ve humoral immün yanıttan oluşan doğal bir immün sisteme sahiptir. Patojenler, akarisitler, fungisitler, herbisitler ve diğer böcek ilaçları arı bağışıklık sistemini ve dolayısıyla arı sağlığını etkiler. Arı bağışıklık sisteminin savunma mekanizmaları sinyal yollarını, patojen tanıma reseptörlerini ve doğal bağışıklık sistemi efektörlerini içerir. Bal arısı kolonilerindeki, salgın infeksiyon riski, bireysel ve sosyal bağışıklık ile azaltılır. Her iki bağışıklık türü birlikte çeşitli düzeylerde hastalıklardan korur, oluşan paraziter ya da diğer infeksiyöz hastalıklara karşı immun yanıt oluşmasında önemli rol oynarlar.
\end{abstract}

Anahtar Kelimeler: Bal Arısı, Patojen, Bireysel Bağışıklık, Sosyal Bağışıklık

\begin{abstract}
Honey bees play an important role in pollination in the natural ecosystem and agricultural field. Many biotic and abiotic stress factors such as pathogens (parasites, fungi, viruses and bacteria), ecosystem changes or losses, use of agricultural chemicals, alone or in combination, adversely affect the health and life of the bee colony. All these factors affect the immune system of the bees and change their defense mechanisms. Honey bees have a natural immune system consisting of physical barriers, generalized cellular and humoral immune response to protect themselves against infectious and parasitic agents. Pathogens, acaricides, fungicides, herbicides and other pesticides affect the bee immune system and hence bee health. Defense mechanisms of the bee immune system include signaling pathways, pathogen recognition receptors and innate immune system effectors. The risk of epidemic infection in honey bee colonies is reduced by individual and social immunity. Both types of immunity protect from diseases at various levels and play an important role in the formation of immune response against parasitic or other infectious diseases.
\end{abstract}

Keywords: Honey Bees, Pathogen, Individual Immunity, Social Immunity

\section{EXTENDED ABSTRACT}

Goal: Honey bees have a natural immune system consisting of physical barriers, generalized cellular and humoral immune response to protect themselves against infectious and parasitic agents. Pathogens, acaricides, fungicides, herbicides and other pesticides affect the bee immune system and hence bee health. Defense mechanisms of the bee immune system include signaling pathways, 


\section{DERLEME MAKALESI / REVIEW ARTICLE}

pathogen recognition receptors and innate immune system effectors. Honey bees have an innate immune system also known as individual immunity. This system is physical barriers and cellular and humoral immunity that play a role in defense against a wide variety of infectious and parasitic microorganisms. In addition to various pathogens that affect bees and stimulate the immune system, xenobiotics such as acaricides, fungicides, herbicides and pesticides are also effective on bee health and immune system. Defense mechanisms include signaling pathways, pathogen recognition receptors, and innate immune system effectors. In order to make bees stronger on their own, these natural defenses should be supported, focusing not only on a single resistance trait, but also focusing on the selection of breeds with many traits such as productivity and resistance traits (e.g. hygienic behavior, grooming, propolis picking). For these various characteristics, rapid and effective evaluation methods of colonies should be developed.

Discussion: The first response of individual immunity is to distinguish between foreign and self. The bee immune system distinguishes infectious agents by recognizing specific proteins present in each pathogen type. The innate immune system of insects includes a variety of responses, including production and secretion of antimicrobial peptides, phagocytosis and pathogens disruption, melanization and encapsulation. When combined with physical barriers, humoral defense mechanisms and different cellular processes, they act together to neutralize parasites, pathogens and xenobiotics, forming a powerful defense. Pathogens and xenobiotics must first cross the physical barriers of honey bees such as the exoskeleton, tracheal tubes, and intestinal mucosa. Bees have basic and natural defenses such as enzymes and hematocytes readily available in hemolymph. Cellular immunity is provided by hemocytes, which are cells carried by hemolymph that perform processes such as phagocytosis, encapsulation and melanization. Humoral immune response is the second category of innate immunity and is the most important defense system of insects including honey bees. It is mediated by chemicals and antimicrobial peptides (AMPs). These are small, highly conserved proteins, usually between 12 and 50 amino acids, produced in response to bacterial and fungal infections and released into insect hemolymph but can be synthesized during viral infections. As social insects, in honey bee colonies, colony individuals cooperate and form superoganisms by displaying collective behavior to combat factors. The term "social immunity" is used to describe the colony level disease protection achieved through the collective defenses of colony members. These defenses include behavioral, organizational, and physiological components.

Conclusion: The risk of epidemic infection in honey bee colonies is reduced by individual and social immunity. Both types of immunity protect from diseases at various levels, and play an important role in the formation of immune response against parasitic or other infectious diseases. There are two types of immune systems in developed vertebrates: natural and acquired immunity. While both act against pathogens, the only line of defense in insects such as honey bees is natural immunity. There are several natural lines of immunity against foreign pathogens at the individual level. Physical and chemical barriers consisting of peritrophic membranes lining the digestive system, the exoskeleton cuticle, are the first lines of defense that prevent pathogens from adhering and entering the body.Social immune processes practiced by honey bees include nest hygiene, secretion of antiseptic compounds to reduce or prevent disease, the collection of plant-derived compounds that improve colony health, thermoregulation changes associated with disease detection and control, and defensive behaviors to protect the nest. We will talk about the immun systems of honey bee from infections play a role.

\section{GíRiş}

Bal arıları, doğal ekosistem ve tarımsal alanda tozlaşmada oldukça önemli rol oynarlar (Evans v.d. 2018). Son yıllarda dünyada arı populasyonu ve koloni kayıpları artmıştır. Patojenler (parazit, mantar, virüs ve bakteriler), ekosistem değişikliği ya da kayıpları, zirai kimyasal kullanımı gibi birçok biyotik ve abiyotik stres faktörü tek başına ya da birlikte arı kolonisi sağlık ve yaşamını olumsuz olarak etkilemektedir. Tüm bu faktörler arıların bağışıklık sistemini etkileyerek savunma mekanizmalarını değiştirir (Brutcher v.d. 2015, Li v.d. 2018, Larsen v.d. 2019).

Tarih boyunca insektler, insan gibi omurgalılardan farklı olarak güçlü ve etkili bir immün sistem geliştirmiştir. İnsektlerin çeşitli patojenlerle 


\section{DERLEME MAKALESi / REVIEW ARTICLE}

mücadele eden eşsiz bağışıklık sistemi, onları dünyadaki en çeşitli ve başarılı hayvanlar haline getirmiştir. Insan dahil omurgalılar, 'immünolojik hafıza' ile hem doğuştan hem de uyarılabilir bağışıklığa sahipken, insektler antikor üretme yeteneğine sahip değildir. Antijenik hafıza eksik gibi görünse de insektler, patojenlere karşı spesifik olmayan bağışıklık reaksiyonları ile karakterize doğuştan gelen bağışıklığa sahiptir. İnsektlerdeki savunma mekanizması hücresel ve humoral bağışıklıktan oluşur (Evans ve Armstrong., 2005, Schmid v.d. 2008, Wilson-Rich v.d. 2008).

Bal arısı kolonilerindeki, salgın infeksiyon riski, bireysel ve sosyal bağışıklık ile azaltılır. Her iki bağışıklık türü birlikte çeşitli düzeylerde hastalıklardan korur, oluşan paraziter ya da diğer infeksiyöz hastalıklara karşı immun yanıt oluşmasında önemli rol oynarlar (DeGrandi-Hoffman ve Chen 2015, Larsen v.d. 2019).

\section{BİREYSEL BAĞıŞIKLIK}

Bal arıları kendilerini infeksiyöz ve paraziter etkenlere karşı korumak için fiziksel bariyerler, genelleşmiş hücresel ve humoral immun yanıttan oluşan doğal bir immun sisteme sahiptir.

Patojenler, akarisitler, fungisitler, herbisitler ve diğer böcek ilaçları arı bağışıklık sistemini ve dolayısıyla arı sağlığını etkiler. Arı bağışıklık sisteminin savunma mekanizmaları sinyal yollarını, patojen tanıma reseptörlerini ve doğal bağışıklık sistemi efektörlerini içerir. Apis mellifera (A. mellifera)'nın bağışıklık sistemi Drosophila sineklerine ve Anopheles sivrisineklerine çok benzese de, bu cinslerde tanımlanan bağışıklık sistemi genlerinin sadece üçte birine sahiptir. Bu nispeten düşük sayıda gen, muhtemelen $A$. mellifera'nın sosyal bağışıklık geliştirmesinin bir sonucudur. Sosyal bağışıklık savunma stratejisi, arıların bireysel bağışıklık sistemi üzerindeki baskıyı azaltır.

Gelişmiş omurgalılarda doğal ve kazanılan bağışıklık olmak üzere iki tip immun sistem vardır. Patojenlere karşı her ikisi de etki gösterirken bal arısı gibi insektlerde tek savunma hattı doğal bağışıklıktır (Larsen v.d. 2019). (Tablo 1)

Tablo1. İnsektler ile yüksek omurgalılardaki doğal bağışıklığın özellikleri (Larsen v.d. 2019)

Table1. Features of natural immunity in higher vertebrates by insects

\begin{tabular}{|c|c|c|}
\hline Özellikler & $\begin{array}{c}\text { Insektler } \\
\text { (Apis mellifera) }\end{array}$ & Gelișmiș omurgalılar \\
\hline Spesifiklik & $\begin{array}{l}\text { Akraba mikroorganizma gruplarının ortak } \\
\text { yapılarına spesifiktir }\end{array}$ & $\begin{array}{l}\text { Akraba mikroorganizma gruplarının } \\
\text { ortak yapılarına spesifiktir }\end{array}$ \\
\hline Reseptör Çeşitliliği & Sınırlı & Sınırlı \\
\hline Hafıza & Önemsiz & Önemsiz \\
\hline Self reaksiyon & Non-spesifik yan zarar & Non-spesifik yan zarar \\
\hline $\begin{array}{l}\text { Humoral efektör } \\
\text { komponentleri }\end{array}$ & $\begin{array}{l}\text { Antimikrobiyal peptitler, tioester bağlantı } \\
\text { proteinleri, melanizasyon ve pıhtılaşma proteinleri }\end{array}$ & $\begin{array}{l}\text { Tamamlayıcı sistem. Sitokinler. } \\
\text { İnterferon sistemi. Kemokinler. } \\
\text { Akut faz proteinleri. Pıntılaşma } \\
\text { sistemi }\end{array}$ \\
\hline $\begin{array}{l}\text { Hücresel efektör } \\
\text { komponentleri }\end{array}$ & $\begin{array}{l}\text { Fagositler } \\
\text { Hemositler }\end{array}$ & $\begin{array}{l}\text { Makrofaj } \\
\text { Dentritik hücreler } \\
\text { Nötrofiller } \\
\text { Doğal bağışıklık lenfositleri } \\
\text { Mastositler }\end{array}$ \\
\hline
\end{tabular}

Bireysel düzeyde yabancı patojenlere karşı birkaç doğal immunite hattı vardır. Dış iskelet kütikulası, sindirim sistemini kaplayan peritrofik membranlardan oluşan fiziksel ve kimyasal bariyerler, patojenlerin vücuda yapışması ve girmesini engelleyen ilk savunma hatlarıdır (Evans v.d. 2006*, Barribeau v.d. 2015, DeGrandi-Hoffman ve Chen 2015, Negri v.d. 2019). Parazit ya da patojenler, fiziksel ve kimyasal korunma sistemlerinden geçerse bal arıları ikinci bir savunma 


\section{DERLEME MAKALESI / REVIEW ARTICLE}

hattı olan hücresel ve humoral bağışıklık tepkileriyle kendilerini koruyabilirler (Barribeau v.d. 2015). Bireysel immunitenin ilk tepkisi yabancı ve kendinden olanı ayırt etmektir. Arı immün sistemi; infeksiyöz etkenleri, her bir patojende mevcut olan spesifik proteinlerini tanıyarak ayırır. Arılar, hemolenfte hazır bulunan enzim ve hemositler gibi temel ve doğal savunmalara sahiptir (Strand 2008, Larsen v.d. 2019).

Insektlerin doğuştan gelen bağışıklık sistemi, antimikrobiyal peptitlerin üretimi ve salgılanması, fagositoz ve patojenlerin imha edilmesi, melanizasyon ve kapsülleme dahil olmak üzere çeşitli tepkiler içerir (Hoffmann 2003).

\section{Fiziksel ve Mekanik Korunma Sistemleri}

Fiziksel bariyerler, humoral savunma mekanizmaları ve farklı hücresel süreçlerle birleştiğinde, parazitleri, patojenleri ve ksenobiyotikleri nötralize etmek için birlikte hareket ederek güçlü bir savunma oluştururlar. Patojenler ve ksenobiyotikler ilk önce bal arılarının dış iskelet, tracheal tüpler ve intestinal mukozası gibi fiziksel sistemleri aşmalıdır. Özellikle virüsler, Varroa ile taşınır ve bu sistemlerden rahatıkla geçebilirler (Larsen v.d. 2019).

Çoğu zaman arı kütikulası ve epiteliyal katmanlar gibi mekanik savunma sistemleri, patojenlerin vücuda yapışmasını ve girmesini önler. Arı kütikulası oldukça güçlü ve suya dayanıklıdır. Bu güçlü kütikula zarar görmediği sürece birçok patojeni tutabilir. Trachea bile su geçirebilen kütikula ile kaplıdır. Kütikula yaralanırsa, açığa çıkan hemolenf (insekt vücut boşluğunu dolduran sıvı, hem "kan" hem de hücre içi lenf işlevi görür, ancak oksijen taşımaz) memelilere benzer şekilde hızla pıhtılaşır. İmmun sistem hücreleri (hemosit) yara kenarından patojenleri içine alır, sonra fenoloksidaz enzimi ile kimyasal aşama başlatıır, hareketsiz ve geçirgen olmayan bariyer oluşturulur. Bu yapı arı vücut tüylerinin kırılmasına, hemolenfin açığa çıkmasına ve doğal olarak da patojenlerin özellikle de virüslerin vücuda girmesine neden olur (Crailsheim ve Riessberger-Gallé 2001, Hoffmann 2003, Larsen v.d. 2019).

Arının en zayıf fiziksel savunma sistemi, dış dünyadan gelen sayısız patojenin bulunduğu arı bağırsağıdır. Ağızdan mideye kadar olan sindirim sistemi, patojenler bu bölgeye yapıştığında değişebilen bir kütikulaya sahiptir. İnsekt bağırsağı peritrofik membran olarak isimlendirilen iç kollardan oluşan kitinöz bir yapı ile korunur. Arı bağırsak lümeni; hafif asidik yapıda, epitelyum hücreleri tarafından üretilen sindirim enzimleri, savunma peptidleri ve bağlayıcı proteinler ile patojen bağlanmasını engelleyici etki gösteren fiziksel, kimyasal ve mekanik savunma sistemleridir (Crailsheim ve Riessberger-Gallé 2001, Haine v.d. 2008, Wilson-Rich v.d. 2008).

Arı larvalarında midgut (mide) ve malpighi tüpleri arka bağırsağa bağlı değildir. Bu nedenle sindirim ve nitrojenli metabolik kalıntılar vücutta depolanır, böylece larvaların etrafındaki gıdaları fekal kontaminasyondan korunur. Larvalar beslenme periyotlarını tamamladıktan sonra ve prepupa döneminden önce mideleri ile malpighi tüpleri fekal materyali atmak için anüs ile bir bağlantı oluşturur. Larvaların sindirim sistemindeki bu anatomik değişiklik hijyen sağlar ve gıdaların mikroorganizmalar için üreme alanına dönüşmesini önler. Prepupal dönemden önce, mide ve arka bağırsak arasında bağlantı olmaması sonucu oluşan sindirim sistemindeki anaerobik koşullar, genç larvaların yaşlı larvalardan çok daha dirençli olmasını sağlar.

Larva sindirim sistemi, vejetatif bakteri formlarının büyümesi için uygun değildir. Larva geliştikçe, ventrikülün iç yüzeyini kaplayan peritrofik zar kalınlaşır ve bu da vejetatif bakteri formlarının yaşlı larvalar için enfektif hale gelmesini önler (Silici 2011, Genç ve Genç 2019).

\section{Hücresel İmmünite}

Patojenlere karşı korunmada immün sistem hücrelerinin rol aldığı bağışıklık türüdür. Hücresel bağışıklık, fagositoz, kapsülleme ve melanizasyon gibi işlemleri gerçekleştiren hücreler olan hemositler hemolenf tarafından taşınır (Strand 2008).

İnsektlerde hemositler, tükürük bezleri ve vücut yağı gibi bağışıklık sisteminin eriyebilir diğer efektör kaynakları ile birlikte antimikrobiyal peptitler gibi humoral efektörleri sentezler ve depolar. Hemositler ayrıca patojenlerle savaşmak için protein üretir bu da yüksek omurgalılardaki karaciğerin fonksiyonel analoğudur (Gillespie v.d. 1997, Brown ve Gordon 2003, Korayem v.d. 2004, Lemaitre ve Hoffmann 2007, Larsen v.d. 2019).

Hücresel mekanizma infeksiyöz ya da yabancı ajanların elimine edilmesinde önemli rol oynar, hemositler bu patojenleri fagosite ederek, parçalayarak ya da nötralize etmek için yutarak etkisiz hale getirir (Strand 2008, Marmaras ve Lampropoulou 2009). 


\section{DERLEME MAKALESI / REVIEW ARTICLE}

Küçük yabancı maddeler hemositler tarafından fagosite edilerek uzaklaştırılırlar. Daha büyükleri ya da küçük maddelerin meydana getirdiği kümelerin uzaklaştırııması için farklı hemositlerin işbirliği ile nodulasyon ve enkapsulasyon başlatılabilir. Bu işlem yabancı madde yüzeyindeki hemositlerin kısmi parçalaması ve kümeleşmesi ile uzaklaştııımasını sağlar. Mikroorganizmaları etkileyen oksijen ve azot aracıları serbest bırakılır, aynı zamanda antioksidan görevi gören proses düzenleyici maddeler eşzamanlı olarak üretilir ve böylece yabancı etkenlerden gelebilecek potansiyel zararlar en aza indirilir (Eleftherianos v.d. 2009, Negri v.d., 2013, Dubovskiy v.d. 2016, Larsen v.d. 2019). İş̧i, kraliçe ve erkek arılar yaşlandıkça hemosit sayıları değişmekle birlikte kapsulasyon mekanizması etkilenmez (Schmid v.d. 2008).

İnsekt hemositleri; morfolojik, histokimyasal ve fonksiyonel özellikleri ile tanımlanmış ve sınıflandırımıştır. Özellikle arılarda, hemolenf sitolojisi farklı yöntemler kullanılarak karakterize edilmiştir. İlk çalışmalarda, \%90'ı plazmositlerle temsil edilen beş ana hemosit tipini tanımlanmıştır (Van Steenkiste, 1988). Daha sonra dört alt tipe ayrımıştır: Prohemositler, pıhtı hemositleri, granüler hücreler ve oenositoidler; son ikisi kapsülleme işlemi sırasında ve sonrasında melanizasyonla ilgilidir (Dubovskiy v.d. 2016). Akış sitometri analizlerinin kullanıldığı bir araştırmada hemositler arasında önemli morfolojik farklılıklar bulamamış ancak iki tip plazmosit tanımlamıştır (de Graaf v.d. 2002). Başka bir çalışmada ise hemolenf hücre grupları, proleukositler, eozinofiller, bazofiller, nötrofiller, piknonükleotitler, adipolökositler, spherukositler, granülositler, makronükleotitler, mikrolökositler ve iğ tipi hücreler olarak sınıflandırılmıştır (Zakaria 2007).

Melanizasyon, kapsülleme veya nodülasyon ile iyileşme sırasında ortaya çıkan humoral ve hücresel süreçlerin bir kombinasyonudur, patojenler veya farklı hasarlarla mücadeleyi amaçlamaktadır. İnsekt savunma sistemindeki bu hücresel reaksiyon, çok sayıda bakteri hücresini, paraziti ve ksenobiyotikleri ortadan kaldırır (Eleftherianos v.d. 2009). Melanizasyonun esas işlevi, patojen yayılımını sınırlamak ve eliminasyon için saklamaktır (Strand 2008).

İnsektlerin bağışıklığında önemli bir rol oynadığı bildirilen en önemli bağışıklık tepkilerinden biri, fenoloksidazın (PO) etkisine dayanan yanıttır (Nappi ve Christensen 2005, Chan v.d. 2009). PO pigmentasyon üreten melanin oluşumunda rol oynar, ancak patojen ve parazitlere karşı koymak için immun yanıtta da kullanılabilir. Pıhtılaşma ve melanizasyon; yaralanma sonucu, yara iyileşme sürecinde entegre edilen karakteristik yanıtlardır (González-Santoyo, 2012).

Profenoloksidaz (proPO), melanizasyona aracılık eden bir hemolenf proteinidir. İnsektlerde proPO'nun aktivasyonu, hemositler tarafından harekete geçirilen patojen tanıma reseptörleri (pathogenrecognition receptors-PRRs) tarafından patojene bağlı moleküler modellerin (pathogen-associated molecular patterns-PAMPs) tanınmasıyla başlayan aşamalı aktivasyon yoluyla gerçekleşir. $\mathrm{Bu}$ aktivasyon patojen ve yabancı maddeler üzerinde yapışma işlemine başlar, üst üste binen bir tabaka oluşturur, maddeleri degranüle etmek veya parçalamak için proPO üretip salgılar. İstilacı ajanı kapsüllemek için melanin oluşumu ve polimerizasyonu (diğer proteinlerle birlikte) ile birlikte, süperoksit anyonu, hidrojen peroksit (Dubovskiy v.d. 2016) ve nitrik oksit (Negri v.d. 2012, Negri v.d. 2013) gibi oksijen ve azotun reaktif aracıları üretilir. Bunlar, etkenlerin yıkımı ve melanizasyonun başlatılması konularında işbirliği yaparlar. Arılar tek bir proPO genine sahipken, Drosophila sp. üç, Anopheles sp.'de ise dokuz tane bulunmaktadır.

proPO-kodlu gen, yetişkin arılarda larva veya pupalara göre daha güçlü bir şekilde eksprese edilir (Lourenco v.d. 2013, Larsen v.d. 2019). Larva gelişiminin erken evrelerinde PO'nun düşük aktivitesi, infeksiyona yatkınlıkla ilişkili gibi görünmektedir (Chan v.d. 2009).

PO aktivasyonunun melanin sentezi ve dolayısıyla A. mellifera bağışıklığı ile ilgisi, arıların ontojenisi ile ilişkilidir (Schmid v.d. 2008, Wilson-Rich v.d. 2008, Laughton v.d. 2011). Gerçekten de melanizasyonun erişkin arılarda enzim aktivitesinin değerlendirilmesi yoluyla önemli bir bağışıkıı yanıtı olduğu ileri sürülmüştür. Bu PO tepkisinin, insekt için yüksek enerjik bir maliyete sahip olduğunu belirtmek önemlidir; enzimin ana aktivasyon sistemi (pro-PO), sadece sindirilen gidalardan elde edilebilen bir bileşik olan fenilalaninden üretilen tirozin'e bağlıdır (González-Santoyo ve Córdoba-Aguilar 2012).

\section{Humoral ve Kimyasal İmmünite}

Humoral immün yanıt, doğal bağışıklığın ikinci kategorisidir ve bal arıları da dahil olmak üzere insektlerin en önemli savunma sistemidir. Kimyasallar ve antimikrobiyal peptitler (AMP'ler) 


\section{DERLEME MAKALESI / REVIEW ARTICLE}

aracılık eder. Bunlar, bakteriyel ve fungal enfeksiyonlara yanıt olarak üretilen ve insekt hemolenfine salınan, ayrıca viral infeksiyonlar sırasında sentezlenebilen, genellikle 12 ila 50 amino asit arasındaki küçük, yüksek oranda korunmuş proteinlerdir (Steinmann v.d. 2015). Bu humoral efektörler insektlerde doğal bağışıklığın temelidir. Bombus pascuorum gibi bazı tozlaşma yapan insektlerde, humoral tepki infeksiyondan sonraki 24 ila 48 saat içinde tespit edilir. Humoral efektörler; hemositler, epiteliyal hücreler ve tükürük bezlerinde üretilebilir, ancak dorsal boşluktaki yağ gövdesi efektör sentezinin ana organıdır (Blum v.d. 1959, Lihoreau v.d. 2015).

Cecropinler, attacinler, dipterisin ve defensinler gibi birkaç AMP ailesi vardır. Bu aktivite birkaç gün sürebilir. Memeli karaciğerinin fonksiyonel analoğu, insekt boşluğunda yeralan ve açık dolaşım sisteminin içinde yer alan büyük bir biyosentetik organdır. Drosophila'da 20'den fazla immünindüklenebilir AMP tanımlanmıştır ve bunlar yedi gruba ayrılmıştır. Küçüktürler (<10 kDa) ve geniş bir anti-bakteriyel spektrum yelpazesi gösterirler. Bal arısında bulunan toplam 4 AMP vardır; apidaecin, abaecin, hymenoptaecin ve defensin (Wilson-Rich, v.d. 2009, Negri v.d. 2019).

Defensinler, Gram-pozitifleri ve mantarları etkilemelerine rağmen, esas olarak E. coli gibi Gram-negatif bakterilere karşı etki eden küçük AMP'lerdir (Yi v.d. 2014). Defensinler için Defensin1 ile Defensin 29 arasında 29 farklı cDNA dizisi vardır. Acabain ve AcAb2 adı verilen iki, abaecin için ise abaecin peptidini kodlayan 11 cDNA dizisi vardır. Apidaecin, dört peptidi kodlayan on üç cDNA dizisine sahiptir: AcAp1 ila AcAp4. Son olarak, 13 farklı peptidi kodlayan hmenoptaekin için 34 farklı cDNA dizisi vardır (Xu v.d. 2009).

Bal arılarının antioksidan enzimleri de ilginçtir, çünkü bunlar reaktif oksijen türlerinin (reactive oxygen species-ROS) detoksifikasyonundan sorumludur. Tüm aerobik organizmalar oksidatif metabolizma prosesi ile ROS üretir (Korayem v.d. 2012, Weirich v.d. 2002). Bu reaktif oksijen türleri, süperoksit anyonu $\left(\mathrm{O}_{2}\right)$, hidroperoksil radikali $\left(\mathrm{HO}_{2}\right)$, hidrojen peroksit $\left(\mathrm{H}_{2} \mathrm{O}_{2}\right)$ ve hidroksil radikalini $(\mathrm{OH})$ içerir. ROS, proteinlerin, RNA'ların ve DNA'ların oksidasyonuna ve membran lipitlerinin peroksidasyonuna neden olabilir. Serbest radikallerin üretimi ile antioksidan üretimi arasındaki dengesizlikler (reaktif ara maddeleri detoksifiye etmek veya ortaya çıkan hasarı onarmak için) canlı hücrelerde oksidatif strese neden olur (Korayem v.d. 2012). Hem süperoksit dismutazlar (SOD'ler) hem de katalaz (CAT), oksijensiz radikallere karşı ilk savunma hatlarıdır. İnsektlerde ayrıca glutatyon Stransferaz, glutatyon peroksidaz ve glutatyon redüktaz da oluşur. İlginç bir şekilde, melanojenik süreçler insektlerlerde etkili bir immun tepki oluşturmak için ROS ve reaktif azot türleri (RNS) ile etkileşime girme kapasitesine sahip sitotoksik moleküllerin oluşumunda rol oynar. Gerçekten de melanogenez sırasında üretilen ROS ve RNS, parazitlerin insektler tarafından öldürülmesinde rol oynar (Nappi ve Christensen 2005).

Nitrik oksit (NO), L-argininin NO sentaz (NOS) enziminin aracılık ettiği citrulin oksidasyonu ile üretilen kararsız bir serbest radikal gaz olan oldukça reaktif bir RNS'dir (Rivero v.d. 2006, Negri v.d. 2019). NO her bir hücre için ya ikinci haberci ya da bitişik hücreler arasında sinyal olarak çalışabilir. NO güçlü bir bakterisidaldir ve parazitlere de etkilidir (Rivero v.d. 2006). Bal arılarında NO, non-self tanınmadan sonra hemosit aktivitesinin ilk basamağında sinyal molekülü olarak görev yapar, özellikle yaralarda iyileşmede, enkapsulasyon ve lipopolisakkarit (LPS) girişine tepkide rol oynar (Negri v.d. 2008, Negri v.d. 2013, Negri v.d. 2017).

Bal arılarındaki humoral immun sistem hakkında birçok bilgi var iken, hücresel bağışıklık hakkında bilgiler sınırlıdır. Hücresel bağışıklık; yara iyileşmesi, fagositoz, virüs öldürme, nodülasyon ve yabancı maddelerin kapsüllenmesini içerir. Tüm bu reaksiyonlarda insekt kan hücreleri, hemositler aracılık eder ve güçlü bir bağışıklık oluşmasını sağlar (Strand 2008, Burritt v.d. 2016, Gábor v.d. 2017, Walderdorff v.d. 2018, Koleoglu v.d. 2018, Annoscia v.d. 2019).

İmmün yanıt genellikle üç aşamalı gerçekleşen olayları içerir; Tanıma, sinyal yollarının aktivasyonu ve patojenleri ortadan kaldırmayı amaçlayan hücresel ve humoral efektör mekanizmalar (Guzman-Novoa 2011). İmmün yanıt, PAMP'lerin immun sistem hücrelerindeki PRR'ler tarafından tanıma işlemiyle başlatılır. Humoral ve hücresel bağışıklıkta rol oynayan efektörlerin ve reseptörlerin yanı sıra peptidoglikan tanıma proteinlerinin (Peptidoglycan recognition proteins-PGRP) sentezini teşvik eden farklı sinyal yolları etkinleştirilir (Dubovskiy 2016). (Şekil1). 


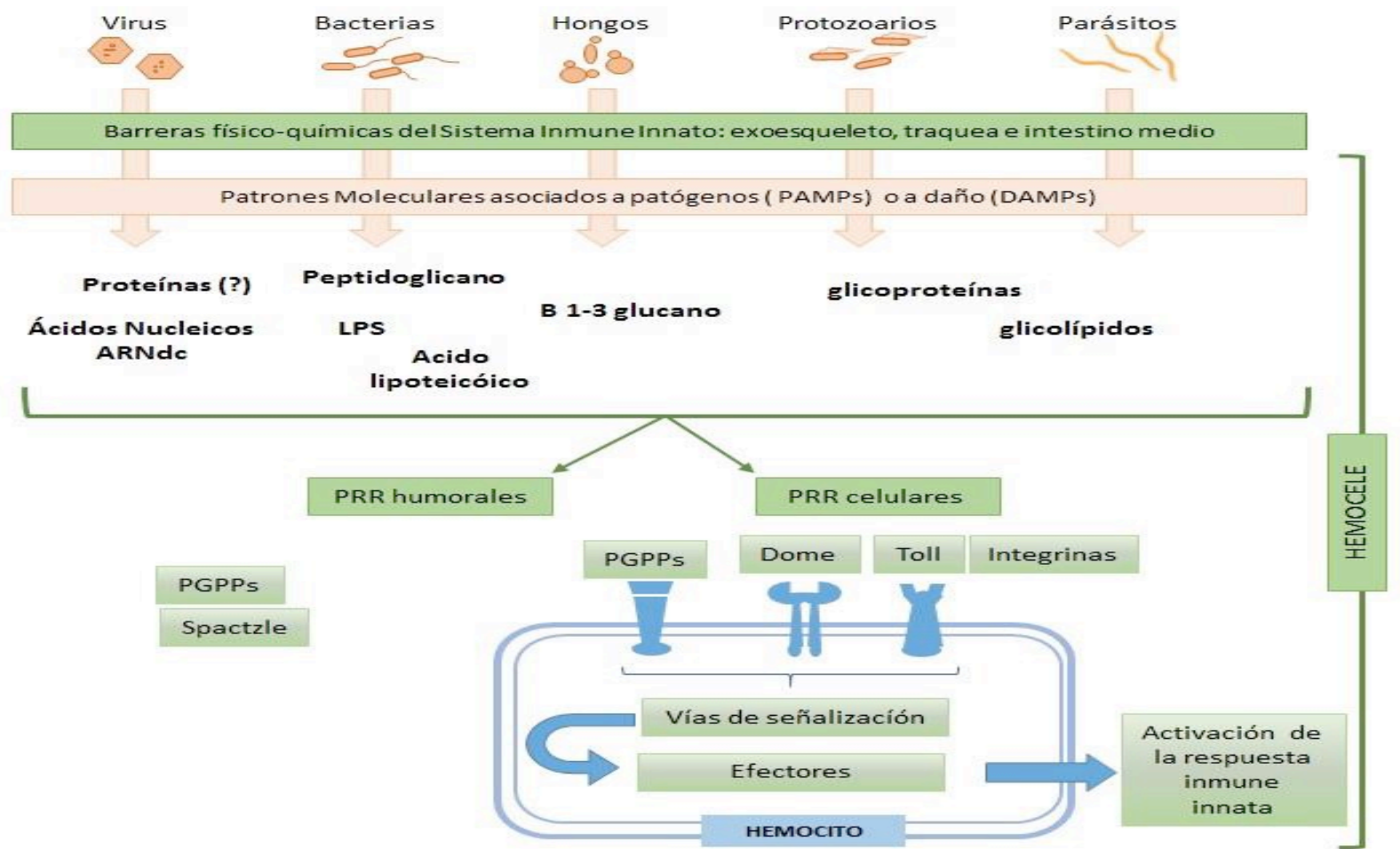

Şekil 1. İmmun Sistem Düzenlenmesi (Larsen v.d. 2019)

Figure1.Immune System Regulation

Drosophila'da PGRP ailesinin bazı üyeleri gibi çoklu PRR'ler oluşur. Drosophila'daki 13 PRR'den, bal arıları dördünü paylaşır, bunlardan ikisi infeksiyonlara yanıt olarak sentezlenir (Toll pathway için PGRP-S2 ve Imd pathway için PGRP-LC). Gram-negatif bakterilerdeki 1,3 glukanı tanıyan GNBP1 gibi diğer proteinler, mantarlar ve bazı Gram-pozitif bakterilerin tanınmasında rol oynar (Wang v.d. 2006, Stokes v.d. 2015). Bu tanıma proteinleri, Spaetzle ve Toll'un Drosophila'daki endojen ligandının bölünmesini başlatan serinproteazlarla ilişkili olabilir; bunların her ikisi de embriyogenez ve immün yanıtta aktive edilir (Valanne v.d. 2011). Arı genomunda Spaetzle familyasından iki ortolog gen tanımlanmıştır (Gravely v.d. 2004, Evans ve Armstrong 2006, Evans 2006, Richard v.d. 2012, Brutscher v.d. 2015).

Doğal immun sistem, etkenlerin Lipopolisakkarit (LPS), lipotheicoic acid, zymosan, glycolipidler, glycoproteinler ve çift sarmallı RNA gibi PAMP'ları tanır (Murphy v.d. 2017). Doğuştan gelen bağışıklık sistemi, termal şok proteini gibi infeksiyöz veya infeksiyöz olmayan hasar görmüş hücrelerde ortaya çıkan hasara bağı molekülleri (Damage-associated molecular patterns-DAMPs) de tanır. Bununla birlikte, insektlerde, virüsle ilişkili moleküler paternleri (Virus-associated molecular patternsVAMP) içeren mikroorganizma ile ilişkili moleküler paternleri (Microbe-associated molecular patternsMAMP) belirtmek daha yaygındır (Brutscher v.d. 2015).

Mikrobiyal yapıların tanınması iki ana olayı tetikler: 1) Toll ve /veya IMD reseptörleri uyarıldığında meydana gelen sinyal olayları ve 2) Fagositoz olayları. Down syndrome cell adhesion molecule (DSCAM) ve Eater genleri, arılardaki endositoz ile ilgili iki gen örneğidir. Drosophila'daki DSCAM'ın hemositler tarafından bakteri tanınmasında rol oynadığı bilinmektedir (Gravely v.d. 2004, Boncristiani v.d. 2012). Peptidoglikanlar, LPS ve zymosan da MAMP'ları tanır. Vitellogenin, bakteriyel fragmanların taşıııcı proteinleridir; transgenerasyon yoluyla kazanılırlar, yeni nesilde doğuştan gelen bağışıklık sisteminin duyarlılaştırılması veya başlatılmasında rol oynarlar. Bu yapılar ekzojen ligandlar olarak işlev görür, çözünür formda veya bağışıklık sistemi hücrelerinde bulunan proteinler 


\section{DERLEME MAKALESI / REVIEW ARTICLE}

veya PRR'ler tarafından tanınır (Hernández López v.d. 2014, Salmela v.d. 2015).

\section{Bal Arılarında İmmün Sistem Sinyal Yolları}

Hücre içi sinyal yolları, dış sinyalleri veya uyaranları hücreler içindeki eylemlere dönüştürerek örneğin konak savunma sistemleriyle ilişkili proteinleri kodlayan bir dizi geni aktive ederek bağışıklık tepkisini indükler. Bal arıları diğer insektler gibi başlıca dört sinyal yoluna sahiptir. Bunlar; Toll, immun yetersizlik (IMD), Janus kinaz-sinyal çevirici (Janus kinase/Signal transducer) ve transkripsiyon aktivatörü (Activator of transcription-JAK-STAT) ve Jun N-terminal kinazlar (JNKs) ile ilişkilidir. Diğer insektler ile karşılaştırıldığında bal arılarında bağışıklık ile ilgili genlerin sayısı insektlerin üçte biri kadardır (Evans v.d. 2006). Bu durum bal arılarının patojenlerle mücadele kapasitesini sınırlayabilir ya da bal arılarındaki bağışıklık mekanizmalarının henüz tam belirlenemediği anlamında da gelebilir.

Bal arısı genomu, insekt bağışıklık yollarının önemli üyelerini kodlar: RNAi (RNA interference), Jak / STAT (Janus kinase/Signal Transducer and Activator of Transcription), Toll, NFkB (Nuclear Factor kB), JNK (c-Jun N-terminal kinase); ve MAPK (Mitogen-Activated Protein Kinases) ve ayrıca otofaji, eikosanoid biyosentez, endositoz ve melanizasyonda rol oynayan ortolog genler (Brutscher v.d. 2015). (Şekil2)

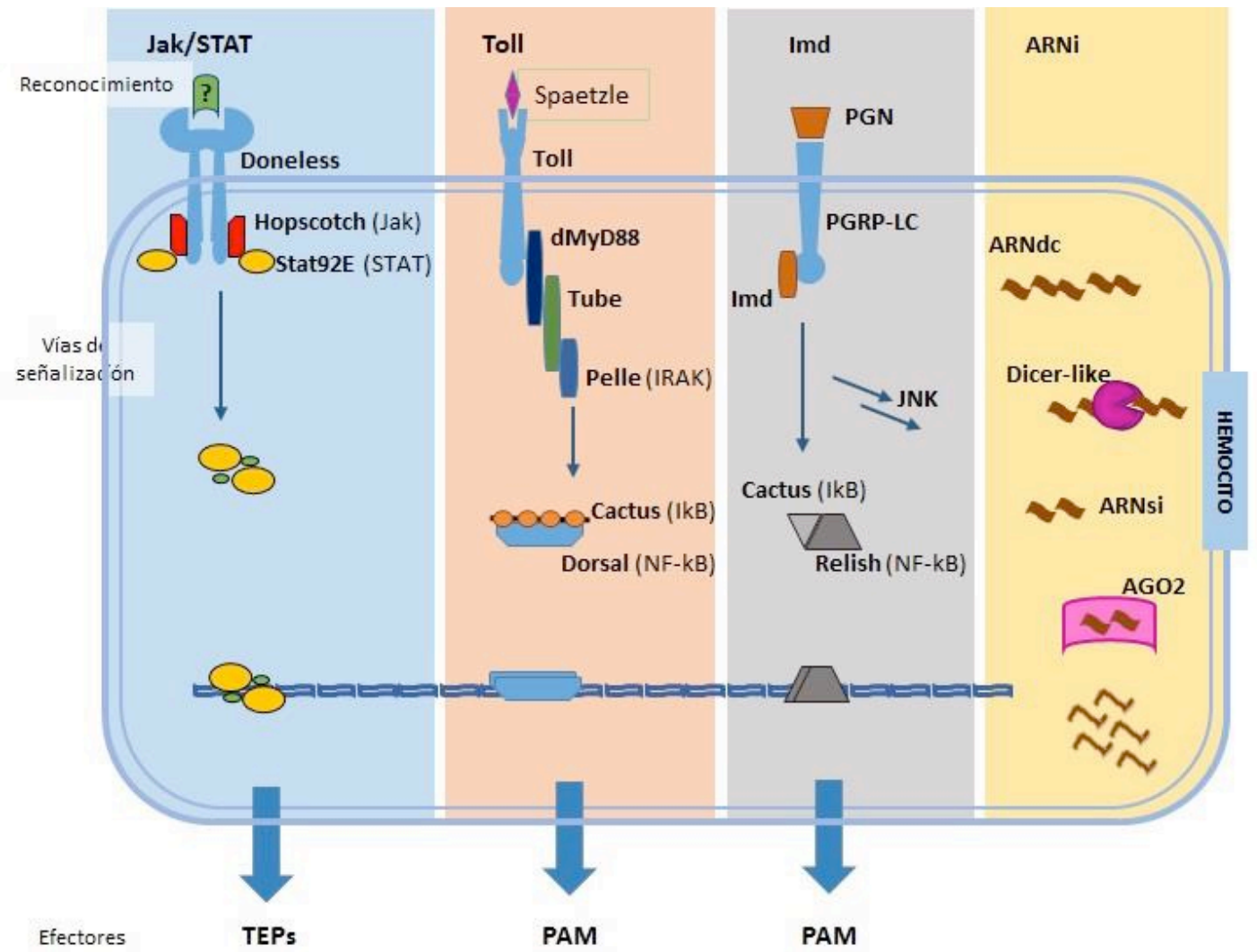

Şekil 2.Sinyal yolları, moleküler ayrıntı (Larsen v.d. 2019).

Figure 2.Signaling pathways, molecular detail

\section{Toll Sinyal Yolu:}

Hücre zarındaki toll reseptörleri hem ontojenik gelişimde hem de bağışıklık sisteminde kritik bir rol oynar. Arılarda Toll ile ilişkili yalnızca beş gen 239 tanımlanmıştır (Toll-1, -6, -2/7, -8, -10); bunlar aynı zamanda birkaç istisna dışında Diptera, Lepidoptera ve Coleoptera takımlarına ait diğer insektlerin genomunda, bulunur. Bu insektlerde bulunan ve

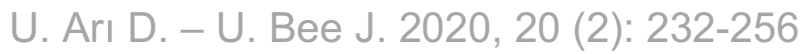




\section{DERLEME MAKALESI / REVIEW ARTICLE}

bulunmayan Toll genlerinin kombinasyonu, bes genin ortak atalarında bulunan temel Toll reseptörlerini kodladığını göstermektedir (Evans v.d. 2006, Brutscher v.d. 2015).

Aktivasyon yolları, çekirdek faktörlerin aktivasyonuna yol açan kinazları aktive eden ve AMP büyüme faktörleri gibi bağışıklık sistemi efektörlerini kodlayan genlerin deregülasyonuna yol açan sitoplazmik adaptör proteinlerinin güçlenmesini içerir. Drosophila'da, sitokin benzeri molekül Spaetzle, transmembran reseptörü Toll'un hücre dışı alanına bağlandığında, Toll sinyal yolu devreye girer. Drosophila genomu, dokuz Drosophila Toll reseptörü için ligand olarak işlev gördüğü düşünülen altı Spaetzle ile ilgili molekül ailesini kodlar (Parker v.d. 2001). Arı genomunda (GB15688 ve GB13503) iki Spaetzle ortologu belirgindir ve hangisinin Tollbağlayıcı sitokinler olarak hareket ettiğini belirlemek için fonksiyonel testlere intiyaç duyulur (Gravely v.d. 2004, Larsen v.d. 2019).

Aktive edilmiş reseptörün konformasyonel değişikliklerini takiben, bir reseptör kompleksi oluşturmak için birkaç hücre içi ölüm alanı (death domain proteins-DD) içeren protein alınır. Aktive edilmiş reseptörün konformasyonel değişikliklerini takiben, bir reseptör kompleksi oluşturmak için birkaç hücre içi ölüm alanı (DD) içeren protein alınır. Bu kompleksin aktivasyonu, CACTUS (counterpart of the NF-kB inhibitor protein, IkB) bozulmasına yol açar ve daha sonra Drosophila'da NF-KB transkripsiyon faktörü DORSAL'ın (Dorsal-related immune factor-Dif) nükleer translokasyonunu sağlar. $\mathrm{Bu}$ da AMP ve lizozimleri aktive eder. Bal arısı genomunda DORSAL'ın iki homologu bulunmuştur (Royet v.d. 2005). Hücre içi bileşenlerin Tollip, Pellino, Kaktin ve TNF reseptörü ile ilişkili faktör2'nin (TRAF-2) bu sinyal yolunda esas elemanlara yardımcı olduğuna inanılmaktadır ve hepsinin her iki sinek türünde ve bal arısında olduğu görülmektedir. Bal arılarında bağışıklık ile ilişkili Toll yolu için aday efektörler arasında bir antimikrobiyal peptit, melanize edici ajan filoksidaz ve üç lizozim bulunmaktadır. Bu efektörlerin diğer yolların aksine Toll pathway tarafından tetiklendiği kanıtlanmamış olsa da arı efektörlerinin bazılarının arıların patojenlerine ya da mekanik yaralanmasına tepki verdiği kesindir (Evans v.d. 2006).

\section{Imd Sinyal Yolu (Immune-deficiency signaling pathway):}

Arı ve sineklerde bağışıklık yetersizliği sinyal yolu (Imd) RELISH transkripsiyon faktörünü (NF-KB transkripsiyon faktörüne homolog) aktive eder. Sineklerde, çoğu AMP'nin ekspresyonunu kontrol eden bu yol mikroorganizmalara karşı bağışıklık tepkisi için zorunludur. Transkripsiyon faktörü inhibitörü olarak CACTUS'in varlığı da gösterilmiştir. $\mathrm{Bu}$ yol, tüm bileşenler için olası ortologlara sahip arılarda oldukça korunmuştur. Bu durum, sinekler ve arılardaki sinyal yollarının benzer olduğunu güçlü bir şekilde göstermesine rağmen, mutlaka aynı biyolojik fonksiyonları paylaştıkları anlamına gelmez (Evans v.d. 2006). Peptid-glukan tanıma proteini (Peptideglucan recognition protein PGRP-LC) aracılığı ile mikroorganizma tanıma, Imd sinyali yolunu aktive eder. Imd yolunun aktivasyonu ayrıca JNK sinyal yolunun bileşenlerinin aktivasyonuna yol açar ve sonraki kontroller AMP sentezinin ekspresyonunu hem pozitif hem de negatif feedback ile kontrol eder. Basket, JNK ve JNK-protein 1 etkileşimi gibi ortologlarının arılarda bulunduğu bilinmektedir (Ryabov v.d. 2014, Larsen v.d. 2019).

Drosophila'da, Imd sinyallemesinin genellikle Gramnegatif bakteriler için spesifik olduğu söylenir, ancak diaminopimelik asit tipi peptidoglikanlara sahip Gram-pozitif bakteriler en az elisitörler kadar güçlüdür. Diğer peptidoglikan türlerine ve hatta mantarlara daha zayıf bir tepki de görülür (Hultmark 2003, Werner v.d. 2003).

Imd sinyal yolu, bal arısında tüm bileşenleri ortologlar ile güçlü bir şekilde korunmuştur. Imd yolunun uyarılmasının, sineklerde ve arılarda benzer olduğu düşüncesi güçlüdür, ancak benzer biyolojik rolleri olmayabilir (Larsen v.d. 2019).

\section{JAK/STAT Sinyal Yolu:}

Insektlerde, JAK / STAT (Janus-family tyirosinkinases [JAK] / transkripsiyon aktivatör proteinleri (Transcription activator proteinsSTAT) sinyalleme yolu, komplement sisteme benzer efektörlerin sentezinde, kan hücreleri tarafından fagositozun proliferasyonunda, indüklenmesinde ve antiviral yanitta rol oynar (Evans v.d. 2006). Başlangıçta gelişim ve hemosit proliferasyonunda rol oynayan JAK-STAT yolu aynı zamanda bakteriyel ve viral infeksiyonlara da yanıt verir (Kingsolver v.d. 2013). JAK / STAT sinyal yolu ayrıca kompleman benzeri faktörlerin indüklenmesi ve hemositlerin aşırı çoğalmasıyla doğal bağışıklıkta rol oynar. JAK / STAT'ın kan hücrelerindeki sitokin benzeri moleküller yoluyla başlatıldığı görülmektedir (Agaisse v.d. 2004). Interleukinler ve interferonlar gibi sitokinler, bu yol boyunca bağışıklık yanıtının 


\section{DERLEME MAKALESI / REVIEW ARTICLE}

düzenlenmesinde ve koordine edilmesinde merkezi bir rol oynar (Negri v.d. 2019, Gupta v.d. 2009).

Sineklerde, ekstrasellüler glikozile protein Upd, hemositlerin fagositik aktivitesini destekleyen JAK / STAT yolunu aktive eden bir ligand görevi görür. Arılarda, JAK / STAT yolu bileşenleri için Drosophila ile beş homolog gen vardır: 1) DOMELESS sitokin reseptörü (DOMELESS cytokine receptor-dom), 2) JAK tirozin kinaz (JAK tyrosine kinase-hopscotch), 3) STAT92E transkripsiyon faktörü, 4) Sitokin sinyalinin (Suppressors of cytokine signaling SOCS) baskılayıcıları, 5) Aktive edilmiş STAT (Protein inhibitor of activated STAT-PIAS) protein inhibitörü gibi negatif yol düzenleyici proteinler. Bu yolun iki ana bileşeni tyrosine phosphatase Ptp61F (XP392429) ve WD40- and bromo-domaincontaining protein BRWD3 (XP395263) ortologdur (Larsen v.d. 2019). JAK / STAT yolu için anahtar ligand (Upd) bal arısı genomunda bulunmasa da gp130 sitokin reseptör homologu Domeless ve sinyal yolunun diğer tüm üyeleri bu mekanizmanın insektler arasında ortak olabilir. Bu yol, arılardaki çeşitli tioester taşıyan proteinler (TEP'ler) gibi bağışıklık sistemi humoral efektörlerini kodlayan genlerin deregulasyonu ile sona ermektedir. Drosophila'daki JAK / STAT yolu, şiddetli stresin neden olduğu humoral faktörleri (Ekengren ve Hultmark 2001, Ekengren v.d. 2001) kodlayan Turandot (Tot) genlerinin ekspresyonunu düzenler. Bal arılarında Tot faktörlerinin hiçbiri (Tot A-Z) görülmez (Evans v.d. 2006).

\section{RNAi sinyal yolu}

Arılardaki VAMP'lerin tanınması, gen replikasyonu için, virüs replikasyon döngüsünü engelleyerek, viral enfeksiyonlara karşı fizyolojik bir savunma mekanizması olan RNA girişim sistemine (RNAi) bağlıdır. Ana RNAi yolu bileşenleri arılardaki viral infeksiyonlarda bulunur; bu işlem sırasında çift sarmallı RNA'lar (double-stranded RNAs-dsRNA) arılardaki DICER like gen tarafından üretilen bir dsRNA sensörü tarafından tanınır (Cornman v.d. 2009, Larsen v.d. 2019). Bu sensör, memelilerde PRR ailesi veya RIG-1 sitosolik sensörler (DICER) ile ilgilidir. DICER dsRNA'yı kestikten sonra, küçük RNA'lar (siRNA) ve microRNA (miRNA) olarak bilinen küçük dsRNA fragmanları, RNA'nın neden olduğu engelleme kompleksi (RISC) tarafından tanınır. İkincisi, AGO2 ailesinin (argonaute-2) proteinlerini içerir, bunlar küçük tek iplikli RNA'lara (ssRNA) dönüşür. Bu küçük ssRNA, tamamlayıcı diziler içeren mRNA transkriptlerine bağlanır, böylece protein sentezini önler. Arılardaki bu yolun aktivasyonu, Drosophila'da bulunan bir ortolog olan vago geninin ekspresyonunun artmasıyla sonuçlanır, bu da viral replikasyonun baskılanmasına neden olur (Ryabov v.d. 2014, Galbraith v.d. 2015). Antiviral fonksiyona sahip arılardaki bir başka epigenetik mekanizma, antiviral yanıtın bir parçası olan DNA metilasyonudur (Galbraith v.d. 2015).

\section{SOSYAL BAĞIŞIKLIK}

Sosyal insektler olarak, bal arısı kolonilerinde, koloni bireyleri işbirliği yapar ve etkenlerle savaşmak için kolektif davranışları göstererek süperoganizmaları oluşturur. Koloni üyelerinin toplu savunmaları yoluyla elde edilen koloni düzeyinde hastalık korumasını tanımlamak için "sosyal bağışıklık" terimi kullanılmaktadır. $\mathrm{Bu}$ savunmalar arasında davranışsal, örgütsel ve fizyolojik bileşenler bulunmaktadır (Cremer v.d. 2007). Sosyal dokunulmazlık davranışları, her bir arının iletişim kurma ve yuva koşullarına cevap verme, daha sonra kolektif süperoganizmayı etkileyen bireysel seçimler yapma yeteneğine dayanır (Negri v.d. 2019).

Sosyal bağışıklık, parazit ve hastalık bulaşmasının kolektif eylemler ve yuva içindeki bireylerin self organizasyon ile nasıl azaltılabileceğini anlamak için yapıcı bir çerçeve sağlar. Bu kolektif savunmalar ya temel ya da uyarılmış olabilir (Simone-Finstrom 2017) ve bireysel bir organizma içindeki bağışıklık sisteminin etkilerine benzerdir (Cremer v.d. 2009).

Bal arıları tarafından uygulanan sosyal bağışıklık süreçleri arasında yuva hijyeni, hastalığı azaltmak veya önlemek için antiseptik bileşiklerin salgılanması, koloni sağlığını geliştiren bitki kaynaklı bileşiklerin toplanması, hastalık tespiti ve kontrolü ile ilişkili termoregülasyon değişiklikleri ve yuvayı korumak için savunma davranışları bulunur (Negri v.d. 2019). (Şekil2). 


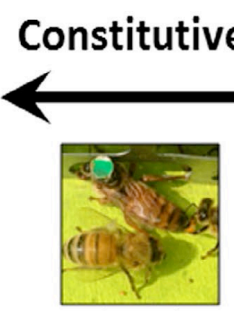

Polyandry

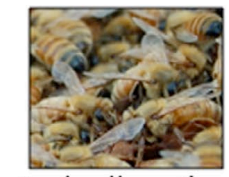

Task allocation

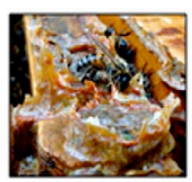

Resin use

(Propolis)
Inducible Traits

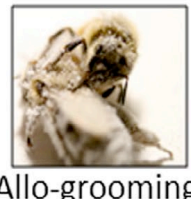

Allo-grooming

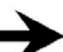

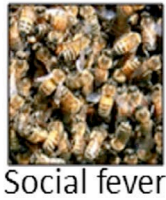

Social fever

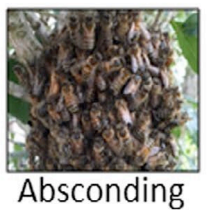

Transfer of compounds and microbiota

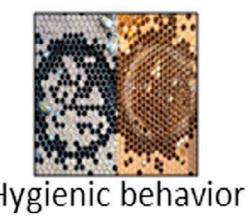

Hygienic behavior

.

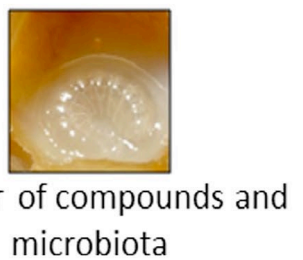

Şekil2. Bal arılarında sosyal bağışıklığa genel bakış (All photos were taken by M. Simone-Finstrom. (Simone-Finstrom 2017).

Figure2. An overview of social immunity in honey bees

Bir bal arısı kolonisindeki yüzlerce veya binlerce birey etkileşime girdiğinde, koloni düzeyindeki sosyal bağışıklık tepkileri, çok hücreli bir organizma içindeki karmaşık humoral ve hücresel bağışıklık sistemlerine benzer özelliklere sahiptir (Cremer v.d. 2009).

\section{Polyandry ve Genetik Çeşitlilik Durumu:}

Bal arılarında kraliçe birden fazla erkek ile çiftleşir ve bu durum polyandry olarak isimlendirilir. Kraliçenin çiftleştiği erkeklerin sayısı, bir koloni içerisindeki baba soylarının veya alt ailelerin sayısını, bu da genetik çeşitlilik düzeyini belirler. Bir kraliçe ne kadar çok erkekle çiftleşirse, yavruları genetik olarak o kadar çeşitli olur. Kraliçeler yaklaşık 5 ila 35 erkekle çiftleşir (ortalama 14) (Tarpy v.d. 2004, Tarpy v.d. 2013). Bu da bazı kolonilerde düşük genetik çeşitliliğe, bazılarında ise aşırı yüksek genetik seviyelere neden olur. Artmış genetik çeşitlilik düzeyine sahip kolonilerin, yiyecek arama verimliliği artar (Eckholm v.d. 2011), arılar daha sağlıklı bağırsak mikrobiyomuna sahip olur (Mattila v.d. 2012). Böyle koloniler genel olarak daha yüksek sağlık ve üretkenlik düzeyine sahip olur (Mattila v.d. 2007). Ayrıca ticari arıcılıkta koloninin hayatını devam ettirme olasılığı daha yüksektir (Tarpy v.d. 2013).

Genetik çeşitliliği yüksek olan koloniler infeksiyonlara daha dirençlidir ve böyle kolonilerde infeksiyonlar daha az ve hafif görülür (Bailey 1999,
Tarpy 2003, Tarpy ve Seeley 2006). Yüksek genetik çeşitlilik seviyelerine sahip koloniler, birden fazla patojen, parazit ve tek bir patojenin farklı suşlarıyla daha iyi mücadele edebilir (Bailey 1999, Vojvodic v.d. 2011, Evison v.d. 2013, Lee, v.d. 2013).

\section{Kolonide Görev Dağılımı (Sosyal Organizasyon):}

Koloni içinde iş bölümü, koloni verimliliğini arttırmanın yanı sıra, koloniler içinde patojenlerin ve parazitlerin yayılmasına karşı önemli bir etkisi vardır. Issçi arılara arasında "polyethism" adı verilen arı yaşına göre görev dağııımı vardır. En genç işçi arılar kovan içinde görevlidir. Kovan bakımı, nektar işleme ve son olarak yiyecek bulma görevlerini yerine getirir, böylece koloninin dışındaki hastalıklardan ve parazitlerden korunurlar. Arılar yiyecek aramayla ilgili görevlere geçtikçe patojenlere maruz kalma riski daha yüksek olur, ancak bu dönemde genç arılarla temas daha az olduğu için genç arılar ve yavrular korunur (Johnson 2010, Simone-Finstrom 2017).

Hijyenik davranış sergileyen (Arathi v.d. 2000) ve infekte bireyleri uzaklaştıran (Visscher 1983)

orta yaşlı arılar daha sonra bakıcı arılar ve larvalarla etkileşime girmez veya yiyecek paylaşmaz, bu da patojen bulaşma riskini azaltır. Büyük ve kalabalık koloniler ergonomik olarak daha verimli olsalar da, patojenlerle daha yüksek temas ve infeksiyon oranlarına sahiptir (Evans v.d. 2010). 


\section{DERLEME MAKALESI / REVIEW ARTICLE}

\section{Temizleme (Tımar) ve Bakım Davranışı:}

Temizlenme genellikle istilacı mikroorganizmalara karşı ilk savunma hattıdır (Zhukovskaya v.d. 2013). Tek bir arı kendini temizleyebilir (otomatik tımar) veya bir arı başka bir arıyı temizleyebilir (genel tımar). Kendini temizleme, yabancı partikülleri ve poleni vücuttan uzaklaştırmak için kullanılır (Jander 1976). Kendini temizleme davranışı daha yaygındır. Arı bacaklarını ve çenesini kullanarak dış parazitleri vücuttan uzaklaştırır (Guzman-Novoa 2011, de Roode ve Lefèvre 2012).

Sosyal bağışıklıkta tımar yapmanın iki büyük etkisi vardır. İlki, bal arısı kolonilerini işgal eden trakeal akar, Acarapis woodi ve $V$. destructor gibi ektoparazitler üzerinedir. Trakeal akarlar için, kendi kendine tımarlama, bireysel infeksiyonu önleyen ana savunmadır (Danka ve Villa 1998, Pettis ve Pankiw 1998, Danka ve Villa 2000). Arının bireysel bakımı, kolonideki akarları da etkili bir şekilde ortadan kaldırabilir. Bu mikroskobik akarlara genetik direnç gösteren arılar, akarları protorasik solungaçtan çıkarırken mezotorasik bacaklarıyla kendilerini temizler, böylece akarların diğer koloni bireylerine bulaşmasını önler (Evans v.d. 2010). Genel bakım sırasında yetişkin arılar yabancı partikülleri ve parazitleri birbirlerinden uzaklaştırırlar (Boecking ve Spivak 1999). Bir arı, diğer arıların özellikle kanatların dibini tımar etmesine neden olan titreme hareketlerini içeren bir "tımar dansı" (Haydak 1945, Milium 1955) ile tımarlamayı başlatabilir. Tımar etmenin akarlara karşı etkili bir savunma olması için, arılar sadece koloni bireyinden foretik akarı çıkarmakla kalmamalı, aynı zamanda akarın idiyomasını veya bacaklarını ısırarak akara zarar vermelidir. Bu durum avantaj olabildiği gibi parazitlerin ve bu parazitlerin taşıdığı viral infeksiyonların bulaşmasına da sebep olabilir (Rosenkranz v.d. 1997, Aumeier, v.d. 2000). (Şekil2)

Tımar etmenin koloni sağlığı ve hastalık direnci üzerinde sahip olacağı diğer etki ise, sosyal bağışıklıktır. Bazı durumlarda hasta bireylerin tımar edilmesi, sonraki patojen tehdidinde bireyin hayatta kalma şansını artıırı (Traniello v.d. 2002, Konrad v.d. 2012).

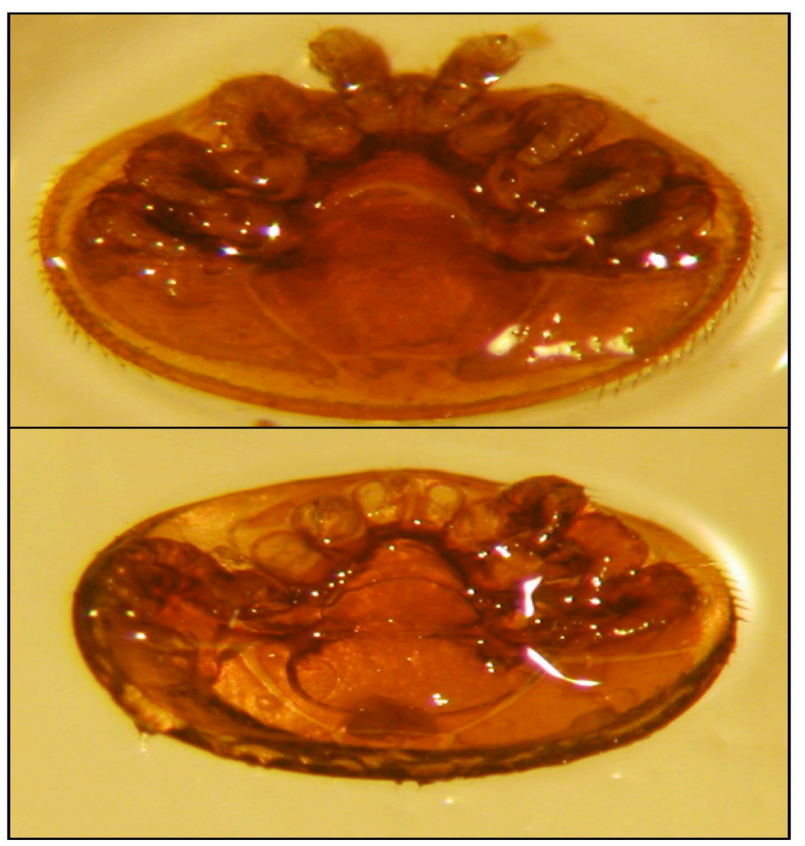

Şekil2. Varroa, tımar hasarına karşı hassastır. Tımar etmek genellikle çiğnenmiş bacaklara veya akar kütikülüne başka hasarlara neden olur (üst: hasar görmemiş akar; alt: birkaç bacak koparılmış akar) USDA photos. (Simone-Finstrom 2017)

Figure 2. Varroa is susceptible to grooming damage. Grooming often causes chewed legs or other damage to the mite cuticle (upper: mite undamaged; lower: mite with several legs plucked off) USDA photos.

\section{Yüksek Düzeyde Uyarılmış Koloni Yanıtları: Termoregülasyon ve Terk Etmek:}

Bal arıları, kuluçka gelişimini desteklemek için yuvalarının içinde doğru sıcaklıkları koruyarak yuva sıcaklıklarını yüksek hassasiyetle düzenleyebilirler (Stabentheiner v.d. 2010).

Bal arıları, ısıtma, soğutma ve havalandırma yoluyla yuvalarının iç ortamını düzenlemek için stratejiler geliştirmişlerdir (Seeley ve Visscher 1985). Yuvada yavru olduğunda, peteklerin sıcaklığını $32-34^{\circ} \mathrm{C}$ civarında tutarlar ve nemdeki dalgalanmaları azaltmak için çaba gösterirler. Özellikle ısıyla düzenleme yeteneği, biyolojik tehditlere karşı bir savunma olarak da kullanılır. Bal arıları tek tek, bir küme içinde toplanarak, yaban arısı, yabancı bir kraliçe veya yırtıcı hayvanın etrafında sıcaklığı en az $45^{\circ} C^{\prime}$ ye yükseltebilir (Esch 1960, Zono v.d. 2005).

Ayrıca, termoregülasyon, "davranışsal ateş (Behavioral Fever)" olarak bilinen yöntemle patojenlere karşı savunmada önemli bir rol oynar. Davranışsal ateş, arıların yuvada ek ISI 


\section{DERLEME MAKALESI / REVIEW ARTICLE}

üretmesinden kaynaklanır. Yuva sıcaklığının yükseltilmesi, özellikle yavrularda kireç hastalığı etkeni Ascosphaera apis'in kontrolüne yardımcı olur. Ascosphaera apis'in infekte ettiği kolonilerde kuluçka sıcaklığında bir artış bildirilmiştir (Starks v.d. 2000).

$\mathrm{Bu}$ "davranışsal ateş" tepkisi, yalnızca sıcaklık değişimlerine duyarlı olabilen kireç hastalığı mantar sporlarının varlığından kaynaklanıyor gibi görünmektedir. Bununla birlikte ateş tepkisi karmaşıktır ve muhtemelen diğer çevresel koşullardan etkilenir (Starks v.d. 2000, SimoneFinstrom v.d. 2014).

Bu davranışın tutarlılığı, genetik geçiş olup olmadığı, diğer patojenlere ve parazitlere olası tepkisi, özellikle bir koloninin yuvayı düzgün ve tutarlı bir şekilde termoregüle etme kabiliyetiyle ilgi olduğu için daha fazla araştırılmalıdır (Jones v.d. 2004, SimoneFinstrom, 2014).

Kolonide infeksiyon, bal arılarının hastalığı yuvadan uzaklaştırmak için ateş, hijyenik davranış, resin toplama gibi özellikler başlatmasına neden olur. Bunlar etkili olmuyorsa ya da infeksiyon şiddetli ise diğer strateji infekte yuvayı geride bırakmak, yeni ve hastalıksız bir kovanda yeni koloni oluşturmaktır. Koloninin tamamı yuvayı terk edebilir, yeni bir yuva bulmak için infekte kovanda yavrulu petekler ve depolanmış gıda maddelerini bırakabilirler. Terk etmek, Afrika ve bazı Asya bal arılarında daha yaygın bir özelliktir. Yüksek düzeyde patojen, parazit veya zararlılar koloniyi işgal ettiğinde Avrupa bal arılarında da görülür. Bu durum genetik olabilir, ancak arı yetiştirciliği bakımından tercih edilir bir özellik değildir (Winston v.d. 1983, Ellis v.d. 2003).

\section{Antimikrobiyal Bileşik Kullanımı:}

İlginç bir şekilde, sosyal insekt yuva mimarisi içinde antimikrobiyal resinler gibi bitki bileşiklerinin kullanımı, birden fazla tür için bir sosyal bağışıklık biçimi olarak kabul edilmiştir (Christe v.d. 2003, Simone v.d. 2009, Drescher v.d. 2014). Bu bileşikler kolonideki bireyler arasında paylaşılır ve tüketilirse, bu da koloninin sağlığını, hayatta kalma oranını ve etkenlerle savaşma yeteneğini arttırırsa sosyal bağışıklık olarak kabul edilmelidir (Spivak v.d. 2019).

a. Bal arısının kendi ürettiği bileşikleri kullanması: İnsektler kendilerini infeksiyöz etkenlerden korumak için çeşitli antimikrobiyal bileşikler üretir. Sosyal insektlerde, bu bileşiklerin çoğunun birden fazla işlevi vardır ve bazı durumlarda, daha sonra koloni düzeyinde patojenlere ve parazitlere karşı bir savunma için seçilen bireysel savunmada kullanılmaktadır (Stow v.d. 2007, Otti, v.d. 2014). Yakın zamandaki çalışmalarda bal arısı kütikülünde zehirli peptitler bulunmuştur (Baracchi ve Cini 2014). Arı venomu antimikrobiyal özelliklere sahiptir (Moreau 2013) ve arı kütikulasına yayılmasının, bazı karınca türlerinde görüldüğü gibi patojenlere karşı doğrudan etkisi olabilir (Tragust v.d. 2013).

Defensin-1 gibi antimikrobiyal peptidler de immun yanıtta önem taşır. Bu antimikrobiyal sekresyonlar, bazı karıncalarda ve termitlerde görüldüğü gibi trophallaxis (arıdan arıya oral transfer) yoluyla transfer edilirse patojen direncini de artırabilir (Hamilton v.d. 2011, Mirabito ve Rosengaus 2016). Benzer şekilde mikrobiyotanın trophallaxis veya kovan ürünlerinin tüketimi yoluyla değişimi hastalık duyarlıı̆ını etkileyebilir ve ayrıca patojenlere karşı koloni düzeyinde dirençte bir faktör olabilir (Koch ve Schimid-Hempel 2011, Powell v.d. 2014).

b. Bitki Bazlı Savunma Bileşiklerinin Toplanması ve Kullanımı: Çeşitli ağaçlar ve odunsu bitkilerin yaprak tomurcuklarını, yaralarını patojen ve pestlere karşı korumak için kimyasal olarak karmaşık resinler üretir (Barnett 2004). Bal arıları bu resinleri yuvalarına taşıyarak gıda olarak kullanır, çeşitli miktarlarda balmumu ile karıştırır ve yuva yapımına dahil eder, bu aşamada karışım propolis olarak adlandırılır (Seeley ve Morse 1976, Ghisalberti 1979, Simone-Finstrom v.d. 2014). Resin ile zengin kolonilerin toplam mikrobiyal yükü daha düşüktür, bu durum arıların bireysel immun sistemlerinin zayıflamasına sebep olabilir (Simone v.d. 2009). Propolis Amerikan yavru çürüklüğü ve kireç hastalığına karşı direkt etki gösterir (Lindenfelser 1968, Antunez v.d. 2008, Simone-Finstrom v.d. 2014, Borba 2015). Yine farklı bileşenleri olan resin Varroa destructor'a karşı direnç mekanizması oluşturur (Popova v.d. 2014).

Bal arılarında propolisin, mikrobiyal yükü azalttığı, immun sistemi düzenlediği, ayrıca chalkbrood (Kireç Hastalığı) infeksiyonlarında bal arılarının resin toplamayı arttırdığı bildirilmiştir (Simone-Finstrom v.d. 2010, Borba 2015). Bu durum, koloni veya süperorganizma düzeyinde çalışan benzersiz bir kendi kendine ilaçlama türüdür. Kireç hastalığı ile infekte olmayan erişkin bal arıları, larvaları infeksiyondan korumak için antimikrobiyal resin toplanmasını arttıır. Bal arılarının ayrıca Varroa ve Deforme Kanat Virüsüne karşı da kendi kendine tedavi (self-medicate) uyguladıkları bildirilmiştir 


\section{DERLEME MAKALESI / REVIEW ARTICLE}

(Drescher v.d. 2017). Bal arıları yuvalarında bitkiler tarafından üretilen bu resinleri toplar ve kullanır. Bal arıları bu resinlerden besin yapar, çeşitli miktarlarda balmumu ile karıştırır ve yuva mimarisine dahil eder, bu noktada karışım artık propolis olarak adlandırılır (Seeley ve Morse 1976, Ghisalberti 1979, SimoneFinstrom v.d. 2010).

Polen, nektar ve bunlarla ilişkili mikrobiyal topluluklar, arılar için besindir, beslenme sağlar ve bağışıklık ve detoksifikasyon sistemi işlevini destekler (Brodschneider ve Crailsheim 2010, Anderson v.d. 2013, Corby-Harris v.d. 2014, Vaudo v.d. 2016, Dolezal ve Toth 2018). Arıların bireysel yiyecek arama tercihleri, koloni düzeyindeki patojen yükünü ve koloni yaşam süresini etkileyebilir (Koch v.d. 2017, Dolezal v.d. 2018), bu nedenle beslenme başı başına bir sosyal bağışıklık biçimi olabilir. Patojen yükünü azaltmak için çeşitli antimikrobiyal özelliklere sahip nektar ve balın tüketilmesi, muhtemelen tüm sosyal arılar için koloni düzeyinde sosyal bağışıklık üzerinde etkili olabilir.

\section{Hijyenik Davranışlar:}

Hijyenik davranış, işçi arıların hastalıklı veya parazit ile enfeste yavruları (larva ve pupa) petek hücrelerinden tespit etme ve uzaklaştırma yeteneğidir. $\mathrm{Bu}$, iki aşamalı bir savunma mekanizmasıdır. İlk olarak, işçiler hastalıkı veya parazit ile enfeste olmuş larva veya pupa içeren hücreleri açar ve sonra bunları yuvadan çıkarır (Guzman-Novoa 2011). Farklı genotiplere sahip arılarda, bu davranış farklıık gösterir. Hijyenik davranış, en az yedi genden oluşan bir gruptan etkilenir, yani karmaşık bir genetik kodlamaya sahiptir. Ayrıca anneden yavrulara geçer. (Rothenbuhler 1964, Lapidge v.d. 2002, Unger ve Guzman-Novoa 2010).

Hijyenik davranış (Rothenbuhler 1964, Spivak v.d. 1998), ilk olarak Amerikan yavru çürüklüğü hastalığında tanımlanmıştır. Varroa ile enfekte olmuş pupanın tespiti durumunda da infekte birey uzaklaştırııır, böylece akarın üremesi azaltııı veya önlenir (Boecking ve Drescher 1991, Harbo ve Harris 2005). Bu son durum genellikle Varroa duyarlı hijyen (Varroa sensitive hygiene-VSH) veya baskılanmış akar üremesi (Suppressed mite reproduction-SMR) olarak bilinen kalıtsal bir özelliktir (Panziera v.d. 2017). Bu davranışa nekroforik davranış da denir. İşçi arılar bir koloni içinde hijyenik davranış sergilediklerinde, bu davranış arı kuluçka hastalıklarına karşı koloni düzeyinde direnç sağlar. Ancak kapalı yavru gözlerindeki anormallikleri saptamak zordur, bu da infekte bireyin uzaklaştırılmasını engelleyebilir (Wilson-Rich v.d. 2009).

Hijyenik davranış, dondurarak öldürülmüş kuluçka yöntemi kullanılarak kolayca değerlendirilebilir; burada petekteki bir kuluçka bölümü sıvı nitrojen kullanılarak dondurulur ve bu ölü pupaların 24 saat sonra uzaklaştırılması belirlenir (Spivak v.d. 1998, Wilson-Rich v.d. 2009). Bu davranışın üç aşaması vardır: algılama, kuluçka kapağını açma ve uzaklaştırma (Arathi v.d. 2000). Kötü hijyenik davranışlı kolonilerde arılar genellikle hastalıklı pupa hücrelerini tekrar kapatır, bu nedenle tam etki için bu üç aşamanın da yapılması gereklidir. Açma ve uzaklaştırma, parazitlerin ve patojenlerin varlığında büyük ölçüde artarken, sürekli denetleme davranışı olarak da gerçekleşir (Arathi v.d. 2006).

Varroa Duyarlı Hijyen (VSH), 1990'ların ortalarından beri arı ıslah programının parçası olarak seçilen bir özelliktir (Harbo ve Harris 2005, Danka v.d. 2016). $\mathrm{Bu}$ seçim programının odak noktası, özellikle uzaklaştırılan akar istilasına uğramış pupaların oranını belirlemektir. Bu yöntem, kuluçka dondurma yönteminden çok daha zaman alır, ancak yüksek VSH ekspresyonuna sahip kolonilerde, bir sezon boyunca popülasyondaki akar oranının oldukça düşük olduğu görülmüştür. $\mathrm{Bu}$ özelliğin diğer patojenlere karşı da etkili olduğu düşünülmektedir (Harbo ve Harris 2001, Ward v.d. 2008).

Hijyenik davranışın diğer bir yönü, hasta veya parazit ile enfeste yetişkin bal arılarının uzaklaştırılmasıdır (Simone-Finstrom 2017). Hasta bireylerin kendilerinin koloniden uzaklaştıkları veya koloniye geri dönemedikleri bilinmektedir (Rueppell v.d. 2010). Ayrıca infeksiyon semptomları gösteren erişkin arılar da aktif olarak uzaklaştırılır (Baracchi, v.d. 2012). Sağlıklı arılar, infekte bireylerdeki kütikular hidrokarbon değişikliklerini veya parazit ile enfeste bireyler tarafından üretilen diğer kimyasal işaretleri belirleyebilme yeteneğine sahiptir. Bu değişiklikler infekte bireylerin uzaklaştırlması için sağlıklı arıları uyarıcı etki gösterir (Salvy v.d. 2001, Richard, v.d. 2008, Swanson v.d. 2009, Schoning v.d. 2012, Mondet v.d. 2016).

Bazen bu davranış, hijyenik kabiliyeti az olan patojen taşıyan bireye temas sonucu koloniye etkenin bulaşmasına sebep olabilir (Evans v.d. 2010). Ancak, infekte yavru ve bireyleri uzaklaştıran arılar genellikle 15-18 günlük olduğu için yavru beslemesi yapan arılardan daha yaşlı olmaları nedeniyle yavrulara bulaşma riskini azaltır (Arathi v.d. 2000).

\section{U. Arı D. - U. Bee J. 2020, 20 (2): 232-256}




\section{DERLEME MAKALESI / REVIEW ARTICLE}

\section{Yuva Savunmacılığı:}

Yetişkin arılar, yırtıcılara ve yağmacılara karşı tepki verirler, yuvayı topluca ve alt türe bağlı olarak az ya da çok saldırgan bir şekilde savunurlar. Bu savunmacı davranış, öncelikle genetiktir, aynı zamanda sosyal olarak feromonlar tarafından modüle edilir ve ekolojik koşullara yanıt olarak ortaya çıkar (Alaux ve Robinson 2007, Nouvian v.d. 2016). Bazı araştırmalar, yüksek saldırganlığın $V$. destructor tarafından düşük enfestasyon, düşük saldırganlığın ise artan pestisit duyarlılığı ile bağlantılı olabileceğini ileri sürmektedir (Martin ve Medina 2004, Rittschof v.d. 2015). Sonuç olarak, yüksek saldırganlık gösteren kolonilerde, akarların yayılması erişkinlerdeki bakım veya hijyenik davranışlardaki varyasyona göre düzenlenerek akar üremesini azaltır. (Arechavaleta-Velasco ve Guzman-Novoa 2001). Ayrica, daha agresif koloniler, daha yüksek oranlarda yiyecek arama eğiliminde oldukları için daha iyi gıda kaynaklarına sahip olabilirler (Negri v.d. 2019).

\section{Simbiyotik Bakteri}

Her canlıda olduğu gibi bal arılarının da vücut ve sistemlerinin bir mikroflorası vardır (Gilliam 1997, Olofsson ve Vásquez 2008). Bu bakteriler arı sağlığı üzerinde olumlu ya da olumsuz rol oynayabilir ve sağlıklı beslenmede de önemlidir (Evans v.d. 2010). Arılardaki bakteriyel mikroflora, kireç hastalığı (Reynaldi v.d. 2004) ve Amerikan yavru çürüklüğü (Evans, v.d. 2005. Evans v.d. 2006) etkenlerinin gelişmesini inhibe eder. Yararlı mikroorganizmaların üremesi desteklenerek patojenlerin gelişmesi engellenir (Evans v.d. 2006).

Bal arıları hem bireysel hem de koloni düzeyinde bağışıklık yeteneğine sahiptir. Arıcılar tarafından patojenleri ve parazitleri kontrol etmek için antibiyotik ve pestisid uygulamaları sık sık yapılır. Bu durum kovan ürünleri ve kovan ekipmanlarında kalıntı problemine, patojen ve parazitlerde ise direnç gelişimine neden olur.

Bal arıları, bireysel bağışıklık olarak da bilinen doğuştan gelen bir bağışıklık sistemine sahiptir. Bu sistem, çok çeşitli bulaşıcı ve parazitik mikroorganizmalara karşı savunmada rol oynayan fiziksel bariyeler ile hücresel ve hümoral bağışıklıktır. Arıları etkileyen ve bağışıklık sistemini harekete geçiren çeşitli patojenlerin yanı sıra akarisitler, fungisitler, herbisitler ve pestisitler gibi ksenobiyotikler de arı sağlığı ve bağışıklık sistemi üzerinde etkilidir. Savunma mekanizmaları sinyal yollarını, patojen tanıma reseptörlerini ve doğuştan gelen bağışıklık sistemi efektörlerini içerir (Larsen v.d. 2019).

Bal arısı yuvalarının kalabalık olması, yiyecek depolarının varlığı ile birlikte, kovanları farklı patojenler için çekici kılar. Bununla birlikte, bu koşullar aynı zamanda, koloni içinde sosyal ateş, tımarlama davranışı, hijyenik davranış ve propolisin toplanması ve kullanılması gibi farklı mekanizmalar aracılığıyla işbirliği davranışı olan sosyal bağışıklığı da teşvik eder. Sosyal bağışıklık, arıların bireysel bağışıkıı sistemi üzerindeki baskıyı büyük ölçüde azaltır (Larsen v.d. 2019). Koloni bireyleri arasındaki koordineli davranışlar, koloni düzeyindeki sosyal bağışıklığın şekillenmesinde rol oynarken, bireysel bağışıkıı tepkisinin de artmasını sağlar. Bir bal arısı kolonisindeki yüzlerce veya binlerce birey etkileşime girdiğinde, koloni düzeyindeki sosyal bağışıklık tepkileri, çok hücreli bir organizma içindeki karmaşık humoral ve hücresel bağışıklık sistemlerine benzer özelliklere sahiptir (Cremer v.d. 2009). Kolonideki bir bireyin sağlık durumuna yanıt verme yeteneği, bir süperorganizma olarak genel bağışıklık yanıtını artırabilir.

Ayrıca modern arı kovanları, bireysel ve sosyal bağışıklık üzerinde doğrudan etkileri olan antimikrobiyal katmanı oluşturan propolis yapımına izin verecek şekilde modifiye edilmiştir. Propolis koloni düzeyinde savunmada ve sosyal bağışıklıkta önemli bir rol oynar. Aynı zamanada patojen ve pestisidlerin balmumunda birikmesini engellemek için eski peteklerin yıllık olarak değiştirilmesi uygun olacaktır.

Bal arıları, patojenler, parazitler, insektisidler ve yanlış bakım-besleme kaynaklı tüm stres etkenlerine rağmen, dirençlidir ve tehditlerle sürekli mücadele etmek için sayısız özelliğe sahiptir. Arıları kendi başlarına daha güçlü hale getirmek için bu doğal savunmaları desteklenmeli, sadece tek bir direnç özelliğine odaklanılmayıp, aynı zamanda üretkenlik ve direnç özellikleri (örneğin hijyenik davranış, tımarlama, propolis toplama) gibi birçok özellliği barındıran ırkların seçimi ön planda olmalıdır. Bu çeşitli özellikler için kolonilerin hızlı ve etkili değerlendirme yöntemleri geliştirilmelidir (Evans v.d. 2010).

\section{KAYNAKLAR}

Agaisse, H., Perrimon, N. 2004. The roles of JAK/STAT signaling in Drosophila immune 


\section{DERLEME MAKALESI / REVIEW ARTICLE}

responses.Immunol Rev. 198:72-82., doi:10.1111/j.0105-2896.2004.0133.x.

Alaux, C., Robinson, GE.2007. Alarm pheromone induces immediate-early gene expression and slow behavioral response in honey bees. $J$ Chem Ecol. 33(7):1346-1350., doi:10.1007/s10886-007-9301-6.

Anderson, KE., Sheehan, TH., Mott, BM., Maes, P., Snyder, L., Schwan, MR., Walton, A., Jones, BM., Corby-Harris, V. 2013. Microbial ecology of the hive and pollination landscape: bacterial associates from floral nectar, the alimentary tract and stored food of honey bees (Apis mellifera). PLoS One. 8(12):e83125., doi:10.1371/journal.pone.0083125.

Annoscia, D., Brown, SP., Di Prisco, G., et al. 2019. Haemolymph removal by Varroa mite destabilizes the dynamical interaction between immune effectors and virus in bees, as predicted by Volterra's model. Proceedings. Biological Sciences 286(1901):20190331., 10.1098/rspb.2019.0331.

doi:

Antunez, K., Harriet, J., Gende, L., Maggi, M., Eguaras, M., Zunino, P. 2008. Efficacy of natural propolis extract in the control of American Foulbrood. Vet Microbiol. 131 (3-4): 324-331., doi: 10.1016/j.vetmic.2008.04.011.

Arathi, HS., Burns, I., Spivak, M. 2000. Ethology of hygienic behaviour in the honey bee Apis mellifera L. (Hymenoptera: Apidae): Behavioural repertoire of hygienic bees. Ethology. 106(4): 365-379., doi.: 10.1046/j.1439-0310.2000.00556.x.

Arathi, HS., Ho, G., Spivak, M. 2006. Inefficient task partitioning among nonhygienic honeybees, Apis mellifera L., and implications for disease transmission. Anim Behav. 72, 431-438., doi: 10.1016/j.anbehav.2006.01.018.

Arechavaleta-Velasco, M., Guzman-Novoa, E. 2001. Relative effect of four characteristics that restrain the population growth of the mite Varroa destructor in honey bee (Apis mellifera) colonies. Apidologie. 32: 157-174., doi: 10.1051/apido:2001121.

Aumeier, P., Rosenkranz, P., Goncalves, L.S., 2000. A comparison of the hygienic response of Africanized and European (Apis mellifera carnica) honey bees to Varroa-infested brood in tropical Brazil. Gen Mol Biol. 23 (4): 787791., doi: 10.1590/S141547572000000400013.

Bailey, L. 1999. The quest for a super-bee. Bee World. 80: 55-60. doi:10.1080/0005772X.1999.11099427.

Baracchi, D., Fadda, A., Turillazzi, S. 2012. Evidence for antiseptic behaviour towards sick adult bees in honey bee colonies. J Insect Physiol. doi:10.1016/j.jinsphys.2012.09.014.

Baracchi, D., Cini, A. 2014. A socio-spatial combined approach confirms a highly compartmentalised structure in honeybees. Ethology. 120: 1167-1176., doi: 10.1111/eth.12290.

Barnett JR. 2004. Langenheim, J.H. Plant resins: chemistry, evolution, ecology and ethnobotany. Ann Bot. 93(6):784-785., doi:10.1093/aob/mch103.

Barribeau, SM., Sadd, BM., du Plessis, L., Brown, MJ., Buechel, SD., Cappelle, K., Carolan, JC., Christiaens, O., Colgan, TJ., Erler, S., et al. 2015. A depauperate immune repertoire precedes evolution of sociality in bees. Genome Biol., 16: 83-103., doi: 10.1186/s13059-015-0628-y.

Blum, MS., Novak, AF., Taber, S. 3rd. 1959. 10Hydroxy-delta 2-decenoic acid, an antibiotic found in royal jelly. Science 130(3373):452453., doi:10.1126/science.130.3373.452.

Boecking, O., Drescher, W. 1991. Response of Apis mellifera L. colonies infested with Varroa jacobsoni Oud. Apidologie. 22 (3): 237-241., doi: 10.1051/apido:19910308.

Boecking, O., Spivak, M., 1999. Behavioral defenses of honey bees against Varroa jacobsoni Oud. Apidologie. 30: 141-158., doi: 10.1051/apido:19990205.

Boncristiani, H., Underwood, R., Schwarz, R., Evans, JD., Pettis, J., vanEngelsdorp, D. 2012. Direct effect of acaricides on pathogen loads and gene expression levels in honey bees Apis mellifera. J Insect Physiol. 58(5): 613-620., doi:10.1016/j.jinsphys.2011.12.011.

Borba, RS. 2015. Constitutive and therapeutic benefits of plant resins and a propolis

U. Arı D. - U. Bee J. 2020, 20 (2): 232-256 


\section{DERLEME MAKALESI / REVIEW ARTICLE}

envelope to honey bee, Apis mellifera L., immunity and health. (3734812 Ph.D.), University of Minnesota, Ann Arbor.

Brodschneider, R., Crailsheim, K. 2010. Nutrition and health in honey bees. Apidologie. 41 (3):278-294., doi:10.1051/apido/2010012.

Brown, GD., Gordon, S. 2003. Fungal beta-glucans and mammalian immunity. Immunity 19(3):311-315., 7613(03)00233-4.

Burritt, NL., Foss, NJ., Neeno-Eckwall, EC., Church, JO., Hilger, AM., Hildebrand, JA., Warshauer, DM., Perna, NT., Burritt, JB. 2016. Sepsis and Hemocyte Loss in Honey Bees (Apis mellifera) Infected with Serratia marcescens Strain Sicaria. PloS one, 11(12): e0167752., doi: 10.1371/journal.pone.0167752.

Brutscher, LM., Daughenbaugh, KF., Flenniken, ML. 2015. Antiviral defense mechanisms in honey bees. Curr Opin Insect Sci.10:71-82., doi: 10.1016/j.cois.2015.04.016.

Chan, QWT., Melathopoulos, AP., Pernal, SF., Foster, L.J. 2009. The innate and systemic response in honey bees to a bacterial pathogen, Paenibacillus larvae. BMC Genom. 10: 387., doi:10.1186/1471-2164-10-387.

Christe, P., Oppliger, A., Bancalà, F., Castella, G. and Chapuisat, M. 2003. Evidence for collective medication in ants. Ecol Lett. 6: 1922., doi:10.1046/j.1461-0248.2003.00395.x.

Cornman, RS., Chen, YP., Schatz, MC., Street, C., Zhao, Y., Desany, B., Egholm, M., Hutchison, S., Pettis, JS., Lipkin, WI., Evans, JD. 2009. Genomic analyses of the microsporidian Nosema ceranae, an emergent pathogen of honey bees. PLoS pathog. 5(6): e1000466., doi:10.1371/journal.ppat.1000466.

Corby-Harris, V., Maes, P., Anderson, KE. 2014. The bacterial communities associated with honey bee (Apis mellifera) foragers. PLoS One. 9(4):e95056., doi:10.1371/journal.pone.0095056.

Crailsheim, K., Riessberger-Gallé, U. 2001. Honey bee age-dependent resistance against American foulbrood. Apidologie 32: 91-104., doi:10.1051/apido:2001114.
Cremer, S., Armitage, SA., Schmid-Hempel, P. 2007. Social immunity. Curr Biol. 2007;17(16): R693-R702., doi:10.1016/j.cub.2007.06.008.

Cremer, S., Sixt, M. 2009. Analogies in the evolution of individual and social immunity. Philos Trans $R$ Soc Lond B Biol Sci. 364(1513):129-142., doi:10.1098/rstb.2008.0166.

Danka, RG., Villa, J.D., 1998. Evidence of autogrooming as a mechanism of honey bee resistance to tracheal mite infestation. J Apic Res. 37: 39-46., doi: 10.1080/00218839.1998.11100953.

Danka, RG., Villa, D., 2000. Inheritance of resistance to Acarapis woodi (Acari: Tarsonemidae) in first-generation crosses of honey bees (Hymenoptera: Apidae). J Econ Entomol. 93: 1602-1605., doi: 10.1603/00220493-93.6.1602.

Danka, RG., Harris, JW., Dodds, GE. 2016. Selection of VSH-derived "Pol-line" honey bees and evaluation of their Varroa-resistance characteristics. Apidologie. 47, 483-490., doi: 10.1007/s13592-015-0413-7.

de Graaf, D., Dauwe, R., Walravens, K., Jacobs, F. 2002. Flow cytometric analysis of lectinstained haemocytesof the honeybee ( Apis mellifera ). Apidologie. 33: 571-579., doi: 10.1051/apido:2002041.

DeGrandi-Hoffman, G., Chen, Y. 2015. Nutrition, immunity and viral infections in honey bees. Curr Opin Insect Sci. 10:170-176., doi: 10.1016/j.cois.2015.05.007.

de Roode, JC., Lefèvre, T. 2012. Behavioral Immunity in Insects. Insects. 3(3):789-820., doi:10.3390/insects3030789.

Dolezal, AG., Toth, AL. 2018. Feedbacks between nutrition and disease in honey bee health. Curr Opin Insect Sci. 26:114-119., doi: 10.1016/j.cois.2018.02.006.

Drescher, N., Wallace, HM., Katouli, M., Massaro, CF., Leonhardt, SD. 2014. Diversity matters: how bees benefit from different resin sources. Oecologia. 76(4):943-953., doi:10.1007/s00442-014-3070-z.

Drescher, N., Klein, AM., Neumann, P., Yañez, O., Leonhardt, SD. 2017. Inside Honeybee Hives: Impact of Natural Propolis on the Ectoparasitic Mite Varroa destructor and 


\section{DERLEME MAKALESİ / REVIEW ARTICLE}

Viruses. Insects. 8(1):15., doi:10.3390/insects8010015

Dubovskiy, I., Kryukova, N., Glupov, V., Ratcliffe, N. 2016. Encapsulation and nodulation in insects. Invert Surviv J. 13(1): 229-246., doi:10.25431/1824-307X/isj.v13i1.229-246.

Eckholm, BJ., Anderson, KE., Weiss, M., DeGrandiHoffman, G. 2011. Intracolonial genetic diversity in honeybee (Apis mellifera) colonies increases pollen foraging efficiency. Behav Ecol Sociobiol. 65: 1037-1044., doi: 10.1007/s00265-010-1108-8.

Ekengren, S., Hultmark, D. 2001. A family of Turandot-related genes in the humoral stress response of Drosophila. Biochem Biophys Res Commun. 284(4):998-1003., doi:10.1006/bbrc.2001.5067.

Ekengren, S., Tryselius, Y., Dushay, M. S., Liu, G., Steiner, H., Hultmark, D. 2001. A humoral stress response in Drosophila. Curr Biol. 11(18):1479., $\quad$ doi:10.1016/s09609822(01)00452-3.

Eleftherianos, I., Felföldi, G., ffrench-Constant, RH., Reynolds, SE. 2009. Induced nitric oxide synthesis in the gut of Manduca sexta protects against oral infection by the bacterial pathogen Photorhabdus luminescens. Insect Mol Biol. 18(4):507-516., doi:10.1111/j.13652583.2009.00899.x.

Ellis, JD., Hepburn, R., Delaplane, KS., Elzen, PJ. 2003. A scientific note on small hive beetle (Aethina tumida) oviposition and behaviour during European (Apis mellifera) honey bee clustering and absconding events. $J$ Apic. Res. 42:

doi:10.1080/00218839.2003.11101089.

Esch, H. 1960. Über die Körpertemperaturen und den Wärmehaushalt von Apis mellifica. Z. Vergl. Physiol. 43: 305-335., doi: 10.1007/BF00298066.

Evans, JD., Armstrong, TN., 2005. Inhibition of the American foulbrood bacterium, Paenibacillus larvae, by bacteria isolated from honey bees. $J$ Apic. Res. 44: 168-171., doi: 10.1080/00218839.2005.11101173.

Evans, JD. 2006. Beepath: an ordered quantitativePCR array for exploring honey bee immunity and disease. J Invertebr Pathol. 93(2): 135139., doi:10.1016/j.jip.2006.04.004
Evans, JD., Armstrong, TN. 2006. Antagonistic interactions between honey bee bacterial symbionts and implications for disease. BMC Ecology 6 (4): 1-9., doi:10.1186/1472-6785-64.

Evans, JD., Aronstein, K., Chen, YP., Hetru, C., Imler, JL., Jiang, H., Kanost, M., Thompson, GJ., Zou, Z., Hultmark, D. 2006. Immune pathways and defence mechanisms in honey bees Apis mellifera. Insect Mol. Biol. 15 (5): 645-656., $\quad$ doi: 10.1111/j.13652583.2006.00682.x.

Evans, JD., Spivak, M. 2010. Socialized medicine: Individual and communal disease barriers in honey bees. J Invertebr Pathol. 103 (Supplement): S62-S72., doi: 10.1016/j.jip.2009.06.019.

Evison, SE., Fazio, G., Chappell, P., Foley, K., Jensen, AB., Hughes, WO. 2013. Hostparasite genotypic interactions in the honey bee: the dynamics of diversity. Ecol Evol. 3(7):2214-2222., doi:10.1002/ece3.599.

Gábor, E., Cinege, G., Csordás, G., Török, T., FolklMedzihradszky, K., Darula, Z., Ando, I., Kurucz, E. 2017. Hemolectin expression reveals functional heterogeneity in honey bee (Apis mellifera) hemocytes. Dev Comp Immunol. 76:403-411., doi: 10.1016/j.dci.2017.07.013.

Galbraith, DA., Yang, X., Niño, EL., Yi S, Grozinger, C. 2015. Parallel epigenomic and transcriptomic responses to viral infection in honey bees (Apis mellifera). PLoS Pathog. 11(3): e1004713. doi:10.1371/journal.ppat.1004713.

Genç, M., Genç, F. 2019. Stress Factors on Honey Bees (Apis mellifera L.) and The Components of Their Defense System Against Diseases, Parasites, and Pests. Mellifera 19 (1): 7-20.

Ghisalberti, EL. 1979. Propolis: A Review. Bee World. 60(2): 59-84., doi:10.1080/0005772X.1979.11097738.

Gillespie, JP., Kanost, MR., Trenczek, T. 1997. Biological mediators of insect immunity. Annu Rev Entomol. 42:611-643., doi:10.1146/annurev.ento.42.1.611.

Gilliam, M. 1997. Identification and roles of nonpathogenic microflora associated with honey 


\section{DERLEME MAKALESI / REVIEW ARTICLE}

bees. FEMS Microbiol Lett. 155:1-10., doi: 10.1111/j.1574-6968.1997.tb12678.x.

González-Santoyo, I., Córdoba-Aguilar, A. 2012. Phenoloxidase: a key component of the insect immune system. Entomol Exp et Appl. 142: 116., doi:10.1111/j.1570-7458.2011.01187.x.

Graveley, BR., Kaur, A., Gunning, D., Zipursky, SL., Rowen, L., Clemens, JC. 2004. The organization and evolution of the dipteran and hymenopteran Down syndrome cell adhesion molecule (Dscam) genes. RNA (New York, N.Y.) 10(10): 1499-1506. doi:10.1261/rna.7105504.

Gupta, L., Molina-Cruz, A., Kumar, S., Rodrigues, J., Dixit, R., Zamora, R. E., Barillas-Mury, C. 2009. The STAT pathway mediates latephase immunity against Plasmodium in the mosquito Anopheles gambiae. Cell Host Microbe. doi:10.1016/j.chom.2009.04.003.

Guzman-Novoa, E. 2011. Integration biotechnologies. Genetic basis of disease resistance in the honey bee (Apis mellifera). In: Murray $\mathrm{M}-\mathrm{Y}$ editor. Comprehensive biotechnology, Second ed. Elsevier (4):763767.

Haine, ER., Moret, Y., Siva-Jothy MT., Rolff, J. 2008. Antimicrobial defense and persistent infection in insects. Science.;322(5905):1257-1259., doi:10.1126/science. 1165265.

Hamilton, C., Lejeune, BT., Rosengaus, RB. 2011. Trophallaxis and prophylaxis: social immunity in the carpenter ant Camponotus pennsylvanicus. Biol Lett. 7(1):89-92., doi:10.1098/rsbl.2010.0466.

Harbo, JR., Harris, JW. 2001. Resistance to Varroa destructor (Mesostigmata: Varroidae) when mite-resistant queen honey bees (Hymenoptera: Apidae) were free-mated with unselected drones. J Econ Entomol. ,94 (6): 1319-1323.

Harbo, JR., Harris, JW. 2005. Suppressed mite reproduction explained by the behaviour of adult bees. J. Apic. Res., 44 (1): 21-23., doi: 10.1080/00218839.2005.11101141.

Haydak, M., 1945. The language of the honeybee. American Bee Journal. 85: 316-317.
Hernández López, J., Schuehly, W., Crailsheim, K., Riessberger-Gallé, U. 2014. Transgenerational immune priming in honeybees. Proceedings. Biological sciences, 281(1785):20140454., doi:10.1098/rspb.2014.0454.

Hoffmann, JA. 2003. The immune response of Drosophila. Nature 426(6962):33-38., doi:10.1038/nature02021.

Hultmark, D. 2003. Drosophila immunity: paths and patterns. Curr Opin Immunol. 15(1):12-19., doi:10.1016/s0952-7915(02)00005-5.

Jander, R., 1976. Grooming and pollen manipulation in bees (Apoidea): the natüre and evolution of movements involving the foreleg. Physiological Entomology. 1: 179-194., doi: 10.1111/j.1365-3032.1976.tb00960.x.

Johnson, BR. 2010. Division of labor in honeybees: form, function, and proximate mechanisms. Behav Ecol Sociobiol. 64: 305-316., doi: 10.1007/s00265-009-0874-7.

Jones, JC., Myerscough, MR., Graham, S., Oldroyd, B. P.2004. Honey bee nest thermoregulation: diversity promotes stability. Science. 305(5682):402-404., doi:10.1126/science.1096340.

Kingsolver, MB., Huang, Z., Hardy, RW. 2013. Insect antiviral innate immunity: pathways, effectors, and connections. J Mol Biol. 425(24):49214936., doi:10.1016/j.jmb.2013.10.006.

Koch, H., Schmid-Hempel, P. 2011. Socially transmitted gut microbiota protect bumble bees against an intestinal parasite. Proc Natl Acad Sci U S A.108(48):19288-19292., doi:10.1073/pnas.1110474108.

Koch, H., Brown, MJF., Stevenson, PC. 2017. The role of disease in bee foraging ecology. Curr Opin Insect Sci. 21: 60-67., doi:10.1016/j.cois.2017.05.008

Koleoglu, G., Goodwin, P.H., Reyes-Quintana, M., Hamudizzaman, MM., Guzman-Novoa, E. 2018. Varroa destructor parasitism reduces hemocyte concentrations and prophenol oxidase gene expression in bees from two populations. Parasitol Res 117: 1175-1183., doi:10.1007/s00436-018-5796-8.

Konrad, M., Vyleta, ML., Theis, FJ., Stock, M., Tragust, S., Klatt, M., Drescher, V., Marr, C., 


\section{DERLEME MAKALESI / REVIEW ARTICLE}

Ugelvig, LV., Cremer, S. 2012. Social transfer of pathogenic fungus promotes active immunisation in ant colonies. PLoS Biol. 10(4):

e1001300.,

doi:10.1371/journal.pbio. 1001300 .

Korayem, AM., Fabbri, M., Takahashi, K., Scherfer, C., Lindgren, M., Schmidt, O., Ueda, R., Dushay, MS., Theopold, U. 2004. A Drosophila salivary gland mucin is also expressed in immune tissues: evidence for a function in coagulation and the entrapment of bacteria. Insect Biochem Mol Biol. 34(12):1297-1304., doi 10.1016/j.ibmb.2004.09.001.

Korayem, AM., Khodairy, MM., Abdel-Aal, AAA., ElSonbaty, AA. 2012. The protective strategy of antioxidant enzymes against hydrogen peroxide in honey bee, Apis mellifera during two different seasons. J. Biol. Earth Sci. 2: B93-B109.

Kurata, S. 2014. Peptidoglycan recognition proteins in Drosophila immunity. Dev Comp Immunol.42(1):36-41., doi:10.1016/j.dci.2013.06.006.

Lamattina, L., Eguaras, M. 2019. Towards Precision Nutrition: A Novel Concept Linking Phytochemicals, Immune Response and Honey Bee Health Insects, 10 (11): 401., doi: 10.3390/insects 10110401.

Lapidge, KL., Oldroyd, B.P., Spivak, M. 2002. Seven suggestive quantitative trait loci influence hygienic behavior of honey bees. Naturwissenschaften. 89: 565-568., doi:10.1007/s00114-002-0371-6.

Larsen, A., Reynaldi, JF., Guzmán-Novoa, E. 2019. Fundaments of the honey bee (Apis mellifera) immune system. Review. Rev Mex Cienc Pecu 10(3):705-728., $\quad$ doi: 10.22319/rmcp.v10i3.4785.

Laughton, AM., Boots, M., Siva-Jothy, MT. 2011. The ontogeny of immunity in the honey bee, Apis mellifera L. following an immune challenge. J Insect Physiol. 57(7):1023-1032., doi: 10.1016/j.jinsphys.2011.04.020.

Lee, GM., McGee, PA., Oldroyd, BP. 2013. Variable virulence among isolates of Ascosphaera apis: testing the parasite-pathogen hypothesis for the evolution of polyandry in social insects.
Naturwissenschaften. 100(3):229-234., doi:10.1007/s00114-013-1016-7.

Lemaitre, B., Hoffmann, J. 2007. The host defense of Drosophila melanogaster. Annu Rev Immunol. 25:697-743., doi:10.1146/annurev.immunol.25.022106.14 1615.

Li, G., Zhao, H., Liu, Z., Wang, H., Xu, B., Guo, X. 2018. The Wisdom of Honeybee Defenses Against Environmental Stresses. Front Microbiol. 9 (722): 1-15., $\quad$ doi: 10.3389/fmicb.2018.00722.

Lihoreau, M., Buhl, J., Charleston, MA., Sword, GA., Raubenheimer, D., Simpson, SJ. 2015. Nutritional ecology beyond the individual: $A$ conceptual framework for integrating nutrition and social interactions. Ecol. Lett. 18 (3): 273286., doi:10.1111/ele.12406.

Lindenfelser, LA. 1968. In vivo activity of propolis against Bacillus larvae. J Invertebr Pathol. 12 (1):129-131., doi: 10.1016/00222011(68)90252-8.

Lourenco, AP., Karina, R., Guidugli-Lazzarini, FCP., Freitas, M., Bitondi, MG., Zilá, LP. et al. 2013. Bacterial infection activates the immune system response and dysregulates microRNA expression in honey bees. Ins Bioch Molec Biol 43(5):474-82., $\quad$ doi: 10.1016/j.ibmb.2013.03.001.

Marmaras, VJ., Lampropoulou, M. 2009. Regulators and signalling in insect haemocyte immunity. Cell Signal. 21(2):186-195., doi:10.1016/j.cellsig.2008.08.014.

Martin, S., Medina, LM. 2004. Africanized honeybees have unique tolerance to Varroa mites. Trends Parasitol. 20: 112-114., doi: 10.1016/j.pt.2004.01.001.

Mattila, HR., Seeley, TD. 2007. Genetic diversity in honey bee colonies enhances productivity and fitness. Science. 317(5836):362-364., doi:10.1126/science.1143046.

Mattila, HR., Rios, D., Walker-Sperlin, VE., Roeselers, G., Newton, ILG. 2012. Characterization of the Active Microbiotas Associated with Honey Bees Reveals Healthier and Broader Communities when Colonies are Genetically Diverse. PLoS ONE 


\section{DERLEME MAKALESI / REVIEW ARTICLE}

7(3): e32962., doi: 10.1371/journal.pone.0032962

Mirabito, D., Rosengaus, RB. 2016. A double-edged sword? The cost of proctodeal trophallaxis in termites. Insect Soc. 63: 135-141., doi: 10.1007/s00040-015-0448-9.

Milium, V. 1955. Grooming dance and associated activities of the honeybee colony.Illionois Academy of Science Transcation. 40: 97-104.

Mondet, F., Kim, S., de Miranda, J., Beslay, D., Conte, YL., Mercer, AR. 2016. Specific Cues Associated With Honey Bee Social Defence against Varroa destructor Infested Brood. Sci Rep. 6: 25444. doi: 10.1038/srep25444.

Moreau, SJM. 2013. "It stings a bit but it cleans well:" Venoms of hymenoptera and their antimicrobial potential. J Insect Physiol. 59(2): 186-204.,

doi: 10.1016/j.jinsphys.2012.10.005.

Murphy, K., Travers, P., Walport, M. 2017. Janeway`s Inmunobiology. 9th ed. London and New York: Garland Science Ed.942 pg.

Nappi, AJ., Christensen, BM. 2005. Melanogenesis and associated cytotoxic reactions: applications to insect innate immunity. Insect Biochem Mol Biol.35(5):443-459., doi:10.1016/j.ibmb.2005.01.014.

Negri, P., Villalobos, E., Szawarski, N., Damiani, N., Gende, L., Garrido, M., Maggi, M., Quintana, S., Schmid, MR., Brockmann, A., Pirk, CWW., Stanley, DW., Tautz, J. 2008. Adult honeybees (Apis mellifera L.) abandon hemocytic, but not phenoloxidase-based immunity. J Insect Physiol. 54 (2): 439-444., doi: 10.1016/j.jinsphys.2007.11.002.

Negri, P., Maggi, M., Massazza, D., CorreaAragunde, N., Eguaras, MJ., Lamattina, L. 2012. Nitric oxide stimulates melanin production during immune response in Apis mellifera. Biocell 36:68., doi: 10.1007/s13592013-0207-8ff. ffhal-01201327f.

Negri, P., Maggi, M., Correa-Aragunde, N., Brasesco, C., Eguaras, M., Lamattina, L. 2013. Nitric oxide participates at the first steps of Apis mellifera cellular immune activation in response to non-self recognition. Apidologie. 44 (5): 575-585., doi:10.1007/s13592-0130207-8.Negri, P., Quintana, S., Maggi, M.,
Szawarski, N., Lamattina, L., Eguaras, M. 2014. Apis mellifera hemocytes generate increased amounts of nitric oxide in response to wounding/encapsulation. Apidologie. 45: 610-617., doi:10.1007/s13592-014-0279-0.

Negri, P., Maggi, M., Ramirez, L., Szawarski A., Feudis, LD., Lamattina, L., Eguaras M. 2016. Cellular immunity in Apis mellifera: studying hemocytes brings light about bees skills to confront threats. Apidologie 47: 379-388., doi: 10.1007/s13592-015-0418-2.

Negri, P., Ramirez, L., Quintana, S., Szawarski, N., Maggi, M., Le Conte, Y., Lamattina, L., Eguaras, M. 2017. Dietary Supplementation of Honey Bee Larvae with Arginine and Abscisic Acid Enhances Nitric Oxide and Granulocyte Immune Responses after Trauma. Insects 8(3): $85 . \quad$ doi: 10.3390/insects8030085.

Negri, P., Villalobos, E., Szawarski, N., Damiani, N., Gende, L., Garrido, M., Maggi, M., Quintana, S., Lamattina, L., Eguaras, M. 2019. Towards Precision Nutrition: A Novel Concept Linking Phytochemicals, Immune Response and Honey Bee Health. Insects 10(11): 401. doi: 10.3390/insects10110401.

Nouvian, M., Reinhard, J., \& Giurfa, M. (2016). The defensive response of the honeybee Apis mellifera. J Exp Biol. 219(Pt 22):3505-3517., doi:10.1242/jeb.143016.

Olofsson, TC., Vásquez, A. 2008. Detection and identification of a novel lactic acid bacterial flora within the honey stomach of the honeybee Apis mellifera. Curr Microbiol. 57(4):356-363., doi:10.1007/s00284-0089202-0.

Otti, O., Tragust, S., Feldhaar, H. 2014. Unifying external and internal immune defences. Trends Ecol Evol. 29(11):625-634., doi:10.1016/j.tree.2014.09.002.

Panziera, D., van Langevelde, F., Blacquière, T. 2017. Varroa sensitive hygiene contributes to naturally selected varroa resistance in honey bees. J. Apic. Res. 56 (5): 635-642., doi: 10.1080/00218839.2017.1351860.

Parker, JS., Mizuguchi, K., Gay, NJ. 2001. A family of proteins related to Spätzle, the toll receptor ligand, are encoded in the Drosophila 


\section{DERLEME MAKALESI / REVIEW ARTICLE}

genome. Proteins 45(1): 71-80., doi:10.1002/prot.1125.

Pettis, JS., Pankiw, T. 1998. Grooming behavior by Apis mellifera L. in the presence of Acarapis woodi (Rennie) (Acari:Tarsonemidae). Apidologie. 29: 241-253., doi: ffhal00891491f.

Popova, M., Reyes, M., Le Conte, Y., Bankova, V. 2014. Propolis chemical composition and honeybee resistance against Varroa destructor. Nat Prod Res. 28(11):788-794., doi: 10.1080/14786419.2014.881366.

Powell, JE., Martinson, VG., Urban-Mead, K., Moran, NA. 2014. Routes of Acquisition of the Gut Microbiota of the Honey Bee Apis mellifera. Appl Environ Microbiol. 80(23):7378-7387., doi:10.1128/AEM.0186114.

Reynaldi, FJ., De Giusti, MR., Alippi, AM. 2004. Inhibition of the growth of Ascosphaera apis by Bacillus and Paenibacillus strains isolated from honey. Rev Argent Microbiol. 36(1):5255.

Richard, F., Aubert, A. \& Grozinger, C. 2008. Modulation of social interactions by immune stimulation in honey bee, Apis mellifera, workers. BMC Biol. 6: 50., doi: 10.1186/17417007-6-50.

Richard, F., Holt, HL., Grozinger, CM. 2012. Effects of immunostimulation on social behavior, chemical communication and genome-wide gene expression in honey bee workers (Apis mellifera). BMC Genomics 13: 558., doi: 10.1186/1471-2164-13-558.

Rittschof, C., Coombs, C., Frazier, M., Grozinger, MC., Robinson, GE. 2015. Early-life experience affects honey bee aggression and resilience to immune challenge. Sci Rep. 5: 15572., doi: 10.1038/srep15572.

Rivero, A. 2006. Nitric oxide: an antiparasitic molecule of invertebrates. Trends Parasitol. 22(5): 219-225., doi: 1016/j.pt.2006.02.014.

Rosenkranz, P., Fries, I., Boecking, O., Sturmer, M., 1997. Damaged Varroa mites in the debris of honey bee (Apis mellifera L) colonies with and without hatching brood. Apidologie. 28: 427437., doi: 10.1051/apido:19970609.
Rothenbuhler, WC. 1964. Behaviour genetics of nest cleaning in honey bees. I. Responses of four inbred lines to disease-killed brood. Anim Behav. 12(4): 578-583., doi:10.1016/00033472(64)90082-X.

Royet, J., Reichhart, JM., Hoffmann, JA. 2005. Sensing and signaling during infection in Drosophila. Curr Opin Immunol. 17(1): 1-17., doi: 10.1016/j.coi.2004.12.002.

Rueppell, O., Hayworth, MK., Ross, N. P. 2010. Altruistic self-removal of health-compromised honey bee workers from their hive. J Evol Biol. 23(7):1538-1546., doi:10.1111/j.14209101.2010.02022.x.

Ryabov, EV., Wood, GR., Fannon, JM., Moore, JD., Bull, JC., Chandler, D., Mead, A., Burroughs, N., Evans, DJ. 2014. A virulent strain of deformed wing virus (DWV) of honeybees (Apis mellifera) prevails after Varroa destructor-mediated, or in vitro, transmission. PLoS pathogens 10(6): e1004230., doi: 10.1371/journal.ppat.1004230.

Salmela, H., Amdam, G. V., Freitak, D. 2015. Transfer of Immunity from Mother to Offspring Is Mediated via Egg-Yolk Protein Vitellogenin. PLoS pathogens 11(7): e1005015., doi: 10.1371/journal.ppat.1005015.

Schmid, MR., Brockmann, A., Pirk, CW., Stanley, DW., Tautz, J. 2008. Adult honeybees (Apis mellifera L.) abandon hemocytic, but not phenoloxidase-based immunity. $J$ Insect Physiol.54(2):439-444., doi:10.1016/j.jinsphys.2007.11.002.

Salvy, M., Martin, C., Bagnères, AG., Provost, E., Roux, M., Le Conte, Y., Clément, JL. 2001. Modifications of the cuticular hydrocarbon profile of Apis mellifera worker bees in the presence of the ectoparasitic mite Varroa jacobsoni in brood cells. Parasitology. 122(Pt 2):145-159., doi:10.1017/s0031182001007181.

Schoning, C., Gisder, S., Geiselhardt, S., Kretschmann, I., Bienefeld, K., Hilker, M., Genersch, E. 2012. Evidence for damagedependent hygienic behaviour towards Varroa destructor-parasitised brood in the western honey bee, Apis mellifera. J Exp Biol. 215: 264-271. doi: 10.1242/jeb.062562. 


\section{DERLEME MAKALESi / REVIEW ARTICLE}

Seeley, TD., Morse, RA. 1976. The nest of the honey bee (Apis mellifera L.). Ins. Soc. 23: 495-512., doi: 10.1007/BF02223477.

Seeley, TD., Visscher, PK., 1985. Survival of honeybees in cold climates: the critical timing of colony growth and reproduction. Ecol Entomol. 10: 81-88., doi: 10.1111/j.13652311.1985.tb00537.x.

Silici, S. 2011. Bal Arısı Biyolojisi ve Yetiştiriciliği. Efil Yayınevi, 240s.

Simone-Finstrom MD., Evans, JD., Spivak, M. 2009. Resin collection and social immunity in honey bees. Evolution. 63(11):3016-3022., doi:10.1111/j.1558-5646.2009.00772.x.

Simone-Finstrom, MD., Spivak, M. 2010. Propolis and bee health: The natural history and significance of resin use by honey bees. Apidologie. $41 \quad$ (3): 295-311., $\quad$ doi: 10.1051/apido/2010016.

Simone-Finstrom, M., Foo, B., Tarpy, DR., Starks, PT. 2014. Impact of Food Availability, Pathogen Exposure, and Genetic Diversity on Thermoregulation in Honey Bees (Apis mellifera). J Insect Behav. 27: 527-539., doi: 10.1007/s10905-014-9447-3.

Simone-Finstrom, MD. 2017. Social Immunity and the Superorganism: Behavioral Defenses Protecting Honey Bee Colonies from Pathogens and Parasites, Bee World. 94(1):21-29., doi: 10.1080/0005772X.2017.1307800.

Spivak, M., Reuter, GS. 1998. Performance of hygienic honey bee colonies in a commercial apiary. Apidologie. 29 (3): 291-302., doi: 10.1051/apido:19980308.

Spivak, M., Goblirsch, M., Simone-Finstrom, M. 2019. Social-medication in bees: the line between individual and social regulation. Curr Opin Insect Sci. 33:49-55., doi: 10.1016/j.cois.2019.02.009.

Stabentheiner, A., Kovac, H., Brodschneider, R. 2010. Honeybee colony thermoregulation-regulatory mechanisms and contribution of individuals in dependence on age, location and thermal stress. PLoS One. 5(1):e8967., doi:10.1371/journal.pone.0008967.
Starks, PT., Blackie, CA., Seeley, TD. 2000. Fever in honeybee colonies. Naturwissenschaften. 87(5):229-231., doi:10.1007/s001140050709.

Steinmann, N., Corona, M., Neumann, P., Dainat, B. 2015. Overwintering Is Associated with Reduced Expression of Immune Genes and Higher Susceptibility to Virus Infection in Honey Bees. PloS one, 10(6): e0129956., doi: 10.1371/journal.pone.0129956.

Stokes, BA., Yadavi, S., Shoka, IU., Smith, LC., Eleftherianos, I. 2015. Bacterial and fungal pattern recognition receptors in homologous innate signaling pathways of insects and mammals. Front Microbiol 6:19., doi:10.3389/fmicb.2015.00019.

Strand, MR. 2008. The insect cellular immune response. Insect Science 15: 1-14., doi:10.1111/j.1744-7917.2008.00183.x.

Stow, A., Briscoe, D., Gillings, M., Holley, M., Smith, S., Leys, R., Silberbauer, T., Turnbull, C., Beattie, A. 2007. Antimicrobial defences increase with sociality in bees. Biol Lett.3(4):422-424. doi:10.1098/rsbl.2007.0178.

Swanson, J. A., Torto, B., Kells, S. A., Mesce, K. A., Tumlinson, J. H., Spivak, M. 2009. Odorants that induce hygienic behavior in honeybees: identification of volatile compounds in chalkbrood-infected honeybee larvae. J Chem Ecol. 35(9):1108-1116., doi:10.1007/s10886009-9683-8.

Tarpy, DR. 2003. Genetic diversity within honeybee colonies prevents severe infections and promotes colony growth. Proc Biol Sci. 270(1510):99-103., doi:10.1098/rspb.2002.2199.

Tarpy, DR., Nielsen, R., Nielsen, DI. 2004. A scientific note on the revised estimates of effective paternity frequency in Apis. Insect. Soc. 51: 203-204., doi:10.1007/s00040-0040734-4.

Tarpy, DR., Seeley, TD. 2006. Lower disease infections in honeybee (Apis mellifera) colonies headed by polyandrous vs monandrous queens. Naturwissenschaften. 93(4):195-199., $\quad$ doi:10.1007/s00114-006$0091-4$. 


\section{DERLEME MAKALESI / REVIEW ARTICLE}

Tarpy, DR., Vanengelsdorp, D., Pettis, JS. 2013. Genetic diversity affects colony survivorship in commercial honey bee colonies. Naturwissenschaften.100(8):723-728., doi:10.1007/s00114-013-1065-y.

Traniello, JF., Rosengaus, RB., Savoie, K. 2002. The development of immunity in a social insect: evidence for the group facilitation of disease resistance. Proc Natl Acad Sci U S A. 99(10): 6838-6842., doi:10.1073/pnas.102176599.

Tragust, S., Mitteregger, B., Barone, V., Konrad, M., Ugelvig, LV., Cremer, S. 2013. Ants disinfect fungus-exposed brood by oral uptake and spread of their poison. Curr Biol. 23(1):76-82. doi:10.1016/j.cub.2012.11.034.

Unger, P., Guzman-Novoa, E. 2010. Maternal effects on the hygienic behavior of Russian $x$ Ontario hybrid honeybees (Apis mellifera L.). $J$ Heredity. 10(1):91-96., doi:10.1093/jhered/esp092.

Valanne, S., Wang, JH., Rämet, M. 2011. The Drosophila Toll signaling pathway. J Immunol. (Baltimore, Md: 1950) 186(2): 649-656., doi: 10.4049/jimmunol.1002302.

Van Steenkiste, D. 1988. De hemocyten van dehonigbij (Apis mellifera L). Typologie, bloedbeeldencellulaireverdedigingsreacties [doctoral thesis]. Gent, Belgium, Rijksuniversiteit.

Vaudo, AD., Patch, HM., Mortensen, DA., Tooker, JF., Grozinger, CM. 2016. Macronutrient ratios in pollen shape bumble bee (Bombus impatiens) foraging strategies and floral preferences. Proc Natl Acad Sci U S A. 113(28): $\quad$ E4035-E4042., doi:10.1073/pnas. 1606101113.

Visscher, P.1983. The honey bee way of death: Necrophoric behaviour in Apis mellifera colonies. Animal Behaviour. 31: 1070-1076.

Vojvodic, S., Jensen, AB., Markussen, B., Eilenberg, J., Boomsma, JJ. 2011. Genetic variation in virulence among chalkbrood strains infecting honeybees. PLoS One. 6(9):e25035.,doi:10.1371/journal.pone.00250 35.

Walderdorff, L., Laval-Gilly, P., Bonnefoy, A., FallaAngel, J. 2018. Imidacloprid intensifies its impact on honeybee and bumblebee cellular immune response when challenged with LPS (lippopolysacharide) of Escherichia coli. J Insect Physiol. 108: 17-24., doi: 10.1016/j.jinsphys.2018.05.002.

Wang, L., Weber, AN., Atilano, ML., Filipe, SR., Gay, NJ., Ligoxygakis, P. 2006. Sensing of Grampositive bacteria in Drosophila: GNBP1 is needed to process and present peptidoglycan to PGRP-SA. The EMBO journal 25(20): 5005-5014., doi: 10.1038/sj.emboj.7601363.

Ward, K., Danka, R., Ward, R. 2008. Comparative performance of two mite-resistant stocks of honey bees (Hymenoptera: Apidae) in Alabama beekeeping operations. J Econ Entomol. 101(3):654-659., doi:10.1603/00220493(2008)101[654:cpotms]2.0.co;2.

Weirich, G., Collins, A., Williams, V. 2002. Antioxidant enzymes in the honey bee, Apis mellifera. Apidologie Springer Verlag 33(1): 314., doi: ff10.1051/apido:2001001ff. ffhal$00891910 f$.

Werner, T., Borge-Renberg, K., Mellroth, P., Steiner, H., Hultmark, D. 2003. Functional diversity of the Drosophila PGRP-LC gene cluster in the response to lipopolysaccharide and peptidoglycan. J Biol Chem. 278(29):2631926322., doi:10.1074/jbc.C300184200.

Wilson-Rich, N., Dres, ST., Starks, PT., 2008. The ontogeny of immunity: development of innate immune strength in the honey bee (Apis mellifera). J Insect Physiol. 54 (10-11): 3921399. doi: 10.1016/j.jinsphys.2008.07.016.

Wilson-Rich, N., Spivak, M., Fefferman, NH., Starks, P. T. 2009. Genetic, individual, and group facilitation of disease resistance in insect societies. Annu Rev Entomol. 54:405-423., doi:10.1146/annurev.ento.53.103106.093301

Winston, ML., Taylor, OR., Otis, GW. 1983. Some differences between temperate European and tropical African and South American honey bees. Bee World. 64: 12-21., doi: 10.1080/0005772X.1983.11097902.

Xu, P., Shi, M., Chen, XX. 2009. Antimicrobial peptide evolution in the Asiatic honey bee Apis cerana. PloS one, 4(1): e4239., doi: 10.1371/journal.pone.0004239. 


\section{DERLEME MAKALESI / REVIEW ARTICLE}

Yi, HY., Chowdhury, M., Huang, YD., Yu, X Q. 2014. Insect antimicrobial peptides and their applications. Appl Microbiol Biotechnol. 98(13): 5807-5822., doi: 10.1007/s00253014-5792-6.

Zakaria, M. 2007. The Cellular Immunity Responses In The Haemolymph of Honey Bee Workers Infected By American Foulbrood Disease (AFB). Res. J. Appl. Sci. 3: 56-63.

Zono, M., Okada, I., Sasaki, M. 2005. Heat production by balling in the Japanese honeybee, Apis cerana japonica as a defensive behavior against the hornet, Vespa simillima xanthoptera (Hymenoptera: Vespidae). Experientia. 43: 1031-1034., doi: 10.1007/BF01952231.

Zhukovskaya, M., Yanagawa, A., Forschler, B. T. 2013. Grooming Behavior as a Mechanism of Insect Disease Defense. Insects. 4(4):609630., doi:10.3390/insects4040609. 